This is an electronic reprint of the original article. This reprint may differ from the original in pagination and typographic detail.

Author(s): Riivari, Elina; Lämsä, Anna-Maija

Title: Does it Pay to Be Ethical? Examining the Relationship Between Organisations' Ethical Culture and Innovativeness

Year: $\quad 2014$

Version:

Please cite the original version:

Riivari, E., \& Lämsä, A.-M. (2014). Does it Pay to Be Ethical? Examining the

Relationship Between Organisations' Ethical Culture and Innovativeness. Journal of Business Ethics, 124(1), 1-17. https://doi.org/10.1007/s10551-013-1859-z

All material supplied via JYX is protected by copyright and other intellectual property rights, and duplication or sale of all or part of any of the repository collections is not permitted, except that material may be duplicated by you for your research use or educational purposes in electronic or print form. You must obtain permission for any other use. Electronic or print copies may not be offered, whether for sale or otherwise to anyone who is not an authorised user. 
DOES IT PAY TO BE ETHICAL? Original article

Does it pay to be ethical? Examining the relationship between organisations' ethical culture and innovativeness

\section{Does it pay to be ethical? Examining the relationship between organisations' ethical culture and innovativeness}

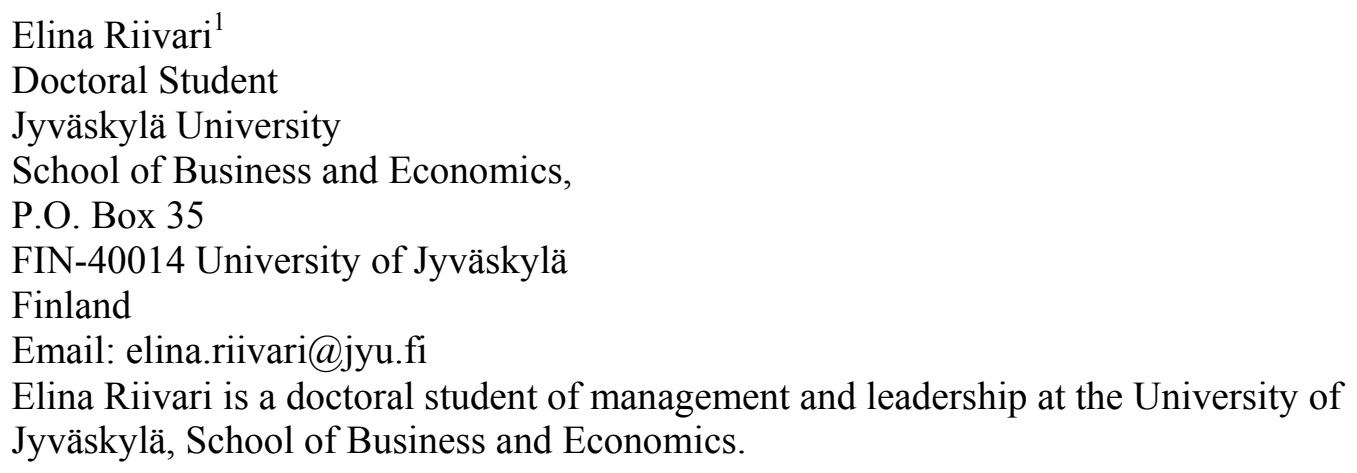

Anna-Maija Lämsä

Professor

University of Jyväskylä

School of Business and Economics,

P.O. Box 35

FIN-40014 University of Jyväskylä

Finland

Email: anna-maija.lamsa@jyu.fi

Anna-Maija Lämsä is a professor of human resource management at the University of Jyväskylä, School of Business and Economics.

\footnotetext{
${ }^{1}$ Corresponding author
} 
Does it pay to be ethical? Examining the relationship between organisations' ethical culture and innovativeness

\begin{abstract}
In this paper we examine the relationship between ethical organisational culture and organisational innovativeness. A quantitative empirical analysis is based on a survey of a total of 719 respondents from all levels of three Finnish organisations, both general staff and managers. The organisations belong to both the private and public sectors. The results of this study show that organisations' ethical culture is associated with their organisational innovativeness, and that different dimensions of ethical culture are associated with different dimensions of organisational innovativeness. The ethical culture of the organisation had a specific role in process and behavioural innovativeness. It was found that congruency of management was the single dimension with the highest effect on organisational innovativeness overall and specifically on process and behavioural innovativeness. These findings suggest that when organisations are aiming for specific outcomes, such as organisational innovativeness, they need to be aware of what dimensions of ethical culture are particularly relevant.
\end{abstract}

Keywords: ethical culture; ethics; innovation; innovativeness; organisational culture; organisational outcomes 
DOES IT PAY TO BE ETHICAL? Original article

Does it pay to be ethical? Examining the relationship between organisations' ethical culture and innovativeness

\section{Introduction}

Recently, researchers in business ethics have been showing increasing interest in the ethical culture of organisations. The concept of the ethical culture of an organisation has been theoretically defined and the validity of the measurement scale has been empirically tested (Kaptein, 2008; Huhtala et al., 2011). Previous studies lend support to the argument that the ethical culture of an organisation promotes positive organisational behaviour and the achievement of organisational outcomes (e.g. Treviño, 1990; Sinclair, 1993; Treviño et al., 1998; Kaptein, 2008, 2009, 2010, 2011; Huhtala et al., 2011; Huhtala et al., 2012). For example, some empirical studies show that an organisation's ethical culture stimulates its managers' occupational well-being (Huhtala et al., 2011) and their commitment to organisational goals (Huhtala et al., 2012), and employees' willingness to report wrongdoing in an organisation (Kaptein, 2011). As the ethical culture of organisations has been found to be positively involved with different outcomes, interest in the phenomenon has increased. However, empirical studies of links between ethical culture and organisational outcomes are still in an early phase; much more empirical research is needed on the topic. This paper aims to contribute by investigating empirically the relationship between organisations' ethical culture and one specific organisational outcome, namely organisational innovativeness.

While scholars have found the topic of ethics interesting and important in the organisational context, it is also increasingly recognized within organisations themselves that ethics plays a critical role in their sustainable performance (e.g. Carroll, 1991; Paine, 1997; Solomon, 2004; Crane and Matten, 2007). In the constantly changing business environment, organisations encounter challenges with conflicting values and interests and need guiding principles and norms to meet these situations successfully (Crane and Matten, 2007). Misconduct in organisations, such as corruption, discrimination, cheating and dishonesty, harm individuals, organisations and also societies. For example, the main cause of Enron's collapse was a lack of attention to ethics in its organisational culture (Sims and Brinkmann, 2003, 2009).

Legal standards, value statements and codes of conduct are important for organisations because they provide the institutional or organisational framework for decent behaviour. However, building and maintaining organisational integrity requires more than just passing laws and making public statements (Paine, 1997). Laws and official rules outline the 
Does it pay to be ethical? Examining the relationship between organisations' ethical culture and innovativeness

minimum level of responsibility (Carroll, 1991) but these formal standards cannot in themselves ensure ethical behaviour (Pučètaitè et al., 2010). This being the case, the organisation's own culture has an important role to play in creating and improving ethical behaviour and in concretising the ethical values of the organisation (Sinclair 1993). Hosmer (1994, 1997) suggests that organisations' and especially managers' moral behaviour (the rightness, justice and fairness of their acts) is important to organisations and their success in the long run.

In this article, we focus on organisational innovativeness as an organisational outcome, which refers to such organisation-level elements as productivity, service and quality (Dyer and Reeves, 1995). We are interested in organisational innovativeness as an organisational outcome which refers to an organisation's behavioural tendency to produce innovative products and services for its customers (Wang and Ahmed, 2004; Baregheh et al., 2009). In the present study we assume that organisational culture influences the achievement of organisational outcomes such as organisational innovativeness, in line with prior research which shows that the organisational culture contributes considerably to the organisation's behaviour (e.g. Brown, 1992; Martins and Terblanche 2003; Erdogan et al. 2006).

Organisational innovativeness has a critical role in the success and survival of many organisations (e.g. Calantone et al. 2002; Salavou 2004). Innovativeness and creativity have an important role in the business world today as the environment is constantly changing. Also the global economy faces different kinds of challenges and organisations have to compete for their position in the market. The worldwide financial crisis and economic recession in Europe have enhanced the importance of creativity and innovativeness in organisations, as they need to come up with new ideas and find ways to compete with fewer resources. Lay-offs and temporary dismissals have also increased in large organisations while at the same time the organisations have to maintain their competitiveness. Many organisations highlight the importance of being innovative but only few succeed in realising it. One reason for the challenges involved could be that innovations are always linked to risk, which might be seen as a threat in an organisation (Ahmed, 1998).

Organisations need innovativeness and new ideas to be competitive (Van de Ven, 1986; Nonaka and Takeuchi, 1995; Quinn, 2000). Innovativeness and creativity are especially 
Does it pay to be ethical? Examining the relationship between organisations' ethical culture and innovativeness

important to expert organisations, which are dependent on knowledge and discovery (Martins and Terblanche 2003; Chang and Birkett 2004). An important factor in creativity and innovativeness has been found to be the culture of the organisation, which can either foster or hinder innovativeness (Martins and Terblanche 2003). A number of studies have found that factors like autonomy, empowerment, purposefulness, collaboration, continuous learning, open communication, conflict handling, diversity, trust, competitiveness, and leadership commitment can support organisational innovativeness (e.g. Mumford 2000; Martins and Terblanche, 2003; Bassett-Jones, 2005; Amabile 2008; Ellonen et al., 2008; Rose-Anderssen and Allen, 2008; Miller and Triana, 2009). Elements of adaptability as opposed to inflexibility and freedom as opposed to control have often been emphasized in previous studies as promoting innovations (Martins and Terblanche 2003).

There have been a large number of studies about organisational innovativeness that have looked at the subject from different perspectives. Various ways have been suggested by which organisations can enhance creativity and innovativeness (see, e.g. Alencar and Bruno-Faria, 1997; Woodman et al., 1993; Ahmed, 1998; Martins and Terblanche, 2003; Välimäki and Lämsä, 2010). However, even if the importance of innovativeness to the success of an organisation has been generally recognised, researchers rarely discuss ethical themes, even though increasing innovation in an organisation may raise ethical considerations. One exception to this is a literature review by Baucus et al. (2008), who found that ethical issues like high risk-taking, breaking rules and challenging authority can be problematic in fostering creativity and innovation. The study by Baucus et al. (2008) supports the idea that more attention should be paid to ethics also when topics related to innovation and creativity are studied. Another study, by Ruppel and Harrington (2000), investigated the influence of fair behaviour on trust, commitment and innovation. Their results also support the idea that moral management and trust are connected to organisational performance and innovativeness. Finally, Riivari et al. (2012) investigated the relationship between the ethical culture of an organisation and innovativeness. Their study indicated that there might be a link between the two. However, this study was only a pilot study in the public sector and had a rather small sample size. This study contributes to empirical research on the ethical culture of organisations (Kaptein, 2008, 2009, 2010, 2011; Huhtala et al., 2011) by focusing on the link between organisations' ethical culture and their organisational innovativeness. 
DOES IT PAY TO BE ETHICAL? Original article

Does it pay to be ethical? Examining the relationship between organisations' ethical culture and innovativeness

The paper is organised as follows. First we will give an overview of the theoretical background of the study, introduce the essential concepts of the study and define the hypotheses set by the literature. The second section begins by describing the study design and then illustrates the results of a quantitative empirical study. Finally, we will present the discussion and conclusion.

\section{Theoretical background and hypotheses}

\section{Ethical culture of organisations}

The discussion of ethics in an organisational context has focused on two concepts, ethical culture and ethical climate (Collier 1998; Treviño and Weaver, 2003; Kaptein, 2008). Ethical climate refers to perceptions and features in the organisation that determine what constitutes ethical conduct (Victor and Cullen, 1988). Ethical culture is defined as those aspects and conventions of organisational behaviour that either encourage the organisation to operate in a sustainable way or deter it from doing so (Kaptein, 2008; Treviño and Weaver, 2003). The main difference between ethical organisational climate and ethical organisational culture is related to the level of analysis. Ethical organisational climate relates to individuals' perceptions and feelings about organisational practices and policies while ethical organisational culture relates to what the organisation ultimately is about (Rentsch, 1990). The former may be described as an element of the latter (Collier 1998). In the field of organisation ethics, earlier research has identified ethical culture as a distinct concept from ethical climate (Treviño and Weaver, 2003).

In this study we apply the Corporate Ethical Virtues Model (CEV) since it formulates normative and multidimensional measures for evaluating the ethical culture of an organisation (Kaptein, 1998, 2008, 2009, 2010). According to Kaptein (2008), the virtuousness of an organisation can be determined by the extent to which the culture of the organisation stimulates its members to act ethically and prevents them from acting unethically. The CEV model consists of eight "virtues" or qualities: clarity, congruency of supervisor, congruency of management, feasibility, supportability, transparency, discussability and sanctionability. According to Kaptein (2008, p. 924), the first three virtues "relate to the self-regulating capacity of the organisation, the next two virtues to the self-providing capacity of the 
Does it pay to be ethical? Examining the relationship between organisations' ethical culture and innovativeness

organisation, and the last three virtues to the self-correcting or self-cleansing capacity of the organisation". The CEV model is based on a virtue-based theory of business ethics (Solomon, $2000,2004)$. According to the theory, organisations should have certain characteristics virtues - in order to be ethical. Ethical virtues provide the conditions for ethical conduct on the part of members of the organisation (Kaptein, 2008).

The first virtue, clarity, refers to expectations concerning the ethical conduct of employees. These expectations need to be explicit and understandable (Kaptein, 2008). It is important for an organisation to make clear the difference between ethical and unethical behaviour as the risk of employees behaving unethically increases if these principles are not clear. The second and third virtues refer to congruency: congruency of supervisors and congruency of management. These two virtues emphasise the importance of the behaviour of supervisors and managers in the organisation and of the example they set. It is important that management behaviour is in line with the formal expectations of the organisation; this indicates to other employees that they should also support these shared expectations.

The fourth virtue, feasibility, concerns the conditions and resources that the organisation provides for its employees to follow the normative expectations (Kaptein, 2008). For example, time, financial resources, equipment and information are examples of the virtue of feasibility. The fifth virtue, supportability, refers to how the organisation helps its employees to meet normative expectations. It is important that employees are able to identify and engage with the normative expectations of the organisation in order to foster ethical behaviour. The virtue of supportability is also an indication of how the organisation encourages and supports such behaviour.

The sixth virtue is transparency and it refers to awareness of the consequences of one's actions in the organisation. Transparency helps employees to take responsibility for their actions and understand what is expected of them in terms of ethical behaviour. Transparency is the degree to which employee conduct and its consequences are perceptible to those who can act upon it, that is, to colleagues, supervisors, subordinates, and the employees concerned. The seventh virtue, discussability, concerns employees' opportunities to discuss ethical issues. Discussability is at a high level if moral conflicts, ethical issues and unethical behaviour can be openly discussed in the organisation. The eighth and last virtue is 
Does it pay to be ethical? Examining the relationship between organisations' ethical culture and innovativeness

sanctionability. It refers to the likelihood of employees being punished for unethical behaviour and rewarded for ethical behaviour. According to Kaptein (2008), it is important that no kind of unethical behaviour is accepted in the organisation, because acceptance at any stage may lead to further tolerance. Also, rewards for ethical behaviour should be considered.

Previous studies on the ethical culture of organisations have found that ethical culture has a positive effect in an organisation. Treviño et al. (1998) found that there is a positive relationship between ethical culture and ethical behaviour as well as between ethical culture and organisational commitment. Kaptein (2011) found that the organisation's ethical culture is related to its employees' intended responses to observed wrongdoings. This finding supports the idea that the ethical culture of an organisation promotes ethical behaviour. Riivari et al. (2012) investigated the role of ethical culture on organisational innovativeness in a pilot study and found that the two are linked. Huhtala et al. (2011) investigated the role of ethical culture in the occupational well-being of managers and found that ethical culture is positively associated with managers' work engagement. The results of these studies indicate that an organisation's ethical culture is linked to different organisational outcomes.

On the basis of the above discussion about ethical culture we set the following hypothesis:

Hypothesis 1: The ethical culture of an organisation is positively related to its organisational innovativeness.

\section{Organisational innovativeness}

We define the concept of organisational innovativeness as the organisation's willingness, tendency and ability to adopt and support new ideas, practices and procedures that may develop into innovations (Lumpkin \& Dess 1996). Innovativeness, the ability to find and support new ideas, is important when the goal of the organisation is to be more successful by improving its products, services and processes (Baregheh et al., 2009). To create innovations, an organisation needs competent people who have the ability to cooperate and integrate their expertise (Belbin, 1981; Roberts and Fusfeld, 1981; Van de Ven, 1986). Individual creativity is also needed for organisational innovativeness (Amabile et al., 1996). 
Does it pay to be ethical? Examining the relationship between organisations' ethical culture and innovativeness

In this study we apply the model of organisational innovativeness developed and validated by Wang \& Ahmed (2004). In previous studies innovativeness has often been defined as a onedimensional construct (Scott \& Bruce, 1994; Salavou 2004). Since innovativeness is nowadays viewed more often as a multidimensional construct, in this study we conceptualize innovativeness in this way, as suggested in the theoretical model of Wang and Ahmed (2004). According to them, organisational innovativeness is seen as "an organization's overall innovative capability of introducing new products to the market, or opening new markets, through combining strategic orientation with innovative behaviour and process" (p. 303). This model includes five dimensions: 1) product innovativeness, 2) market innovativeness, 3) process innovativeness, 4) behavioural innovativeness and 5) strategic innovativeness.

According to Wang \& Ahmed (2004), the first dimension, product innovativeness, refers to the newness of the organisation's products and services. It also includes reference to the right timing of the products and/or services. The second dimension, market innovativeness, includes the novelty of the approaches that organisations use to access and reach the targeted customers. The third dimension is process innovativeness, which refers to the opening of new production methods, new management styles and new technology that can be used to enhance production and management systems. The fourth, behavioural innovativeness, is related to the organisation's members', teams' and management's internal interest in new ideas and innovations. Finally, the fifth dimension, strategic innovativeness, is related to an organisation's ability to achieve determined organisational objectives, to recognize any disparity between its ambitions and its existing resources, and to exploit its limited resources creatively.

Organisational innovativeness is necessary for creating innovations and so it is important to focus on its development (Wang \& Ahmed 2004). Organisations where the environment is open to new ideas and creativity and to actively seeking new opportunities have the most important features of being innovative and have the potential to innovate (Ahmed, 1998; Judge et al., 1997; Martins and Terblanche, 2003; Välimäki and Lämsä, 2010; Westwood and Low, 2003). Such elements as challenges, autonomy, team support, supervision and encouragement have been seen as the main characteristics of an innovative work environment. Also trust, opportunities to participate, and the sharing of information and learning are mentioned as essential factors in creating an innovative organisational culture. 
Does it pay to be ethical? Examining the relationship between organisations' ethical culture and innovativeness

(Ellonen et al. 2008; Rebernik and Širec, 2007; Roffe, 1999; Scott and Bruce, 1994; Wang and Ahmed, 2004.) These features are closely related to the ethical virtues of supportability, feasibility and discussability in the CEV model (Kaptein 2008), which could indicate that some ethical virtues might be linked to organisational innovativeness in a different way from others.

Riivari et al. (2012) found in their pilot study in the Finnish public sector that there is a positive link between the ethical culture of an organisation and organisational innovativeness. In this study the ethical culture was found to be important to behavioural, strategic and process innovativeness. Riivari et al. (2012) also reported that congruence of management was the most significant dimension of ethical culture in relation to innovativeness. Previous studies therefore suggest that the ethical culture of organisations is associated with organisational innovativeness, with various dimensions of ethical culture being differently associated with some dimensions of organisational innovativeness. Therefore we present the following hypothesis:

Hypothesis 2: Different dimensions of an organisation's ethical culture are related to different dimensions of its organisational innovativeness.

\section{Method}

\section{Sample}

The empirical data for this study were collected by means of a standardised questionnaire that was sent to three Finnish organisations in November and December 2011. The questionnaire was sent to a total of 1395 people, of whom 719 responded. The organisations belong to both the private and public sectors. Organisation A is a large public sector organisation and Organisations $\mathrm{B}$ and $\mathrm{C}$ are both private sector companies that operate in industrial services. Organisation B is a medium sized company operating in industrial services mainly in Finland. Organisation $\mathrm{C}$ is a large company operating in industrial services in the Nordic countries and in Eastern Europe; its head office is in Finland and Finland is its main market area.

The questionnaire was available as an Internet survey in all three organisations and also on paper in Organisation C. In Organisations A and B the online questionnaire was available to 
Does it pay to be ethical? Examining the relationship between organisations' ethical culture and innovativeness

all employees. In Organisation $\mathrm{C}$ the questionnaire was available online to all clerical and expert workers and it was distributed in paper format to all the employees in one regional unit in Finland chosen by those we contacted in the company's management group. Two options for participating in the questionnaire were chosen in Organisation $\mathrm{C}$ in order to increase the response rate and to reach as many respondents as possible. The researcher posted the questionnaires to contact persons, team managers in different units of the one large regional unit of Company $\mathrm{C}$, and the managers passed the questionnaire on to the people working in their teams. We wanted to use contact persons inside the company to deliver the questionnaires as it is commonly known that people take research more seriously if someone inside the organisation is involved with the study.

The sample size in Organisation A was 715, from whom 477 responses were received; this was a response rate of 67 per cent. The sample size in Organisation B was 250, of whom 124 responded. The total response rate in Organisation B was 50 per cent. In Organisation C the sample size was in total 430, from whom 118 usable responses were received. The total response rate in Organisation C was 27 per cent. The online survey was available to 289 people, 103 of whom responded (36\%), while the paper questionnaire was distributed to a total of 141 people, 15 of whom returned usable responses $(8 \%)$. The final response rate was 51.5 per cent (719/1395), which can be considered very high in this type of study (Baruch and Holtom, 2008).

In Organisation $\mathrm{A}$, the average age of the respondents was 48 years, with an age range from 24 to 66 (SD 11.14). 40\% ( $\mathrm{n}=190)$ of the participants were men and $60 \%(\mathrm{n}=287)$ women. Of the participants, $83 \%$ were experts/specialists, $11 \%$ managers, and $6 \%$ other employees. $78.4 \%$ of the participants had a university degree, and $21.6 \%$ a vocational or college degree. The participants had been in working life for an average of 23 years (SD 11.31) and had been working in their current position for an average of 13 years (SD 9.78). Almost all of the respondents in organisation A worked full time (92\%) and had permanent employment (96 $\%)$.

In Organisation B, the average age of the respondents 45 years, with an age range from 25 to 64 (SD 10.60). $79 \%(n=98)$ of the participants were men and $21 \%(n=26)$ women. Of the participants, $83 \%$ were experts/specialists and $17 \%$ managers. $73.4 \%$ of the participants had a 
Does it pay to be ethical? Examining the relationship between organisations' ethical culture and innovativeness

university degree, and $26.6 \%$ a vocational or college degree. The participants had been in working life for an average of 20 years (SD 11.83) and had been working in their current position for an average of 8 years (SD 5.59). Almost all of the participants in Organisation B worked full time (98\%) and had permanent employment.

In Organisation $\mathrm{C}$, the average age of the respondents was 44 years, with an age range from 24 to 61 (SD 10.41). $77 \%(n=91)$ of the participants were men and $23 \%(n=27)$ women. Of the participants, $59 \%$ were experts/specialists, $10 \%$ managers, and $31 \%$ other employees. $41.5 \%$ of the participants had a university degree, and $58.5 \%$ a vocational or college degree. The participants had been in working life for an average of 21 years (SD 10.96) and had been working in their current position for an average of 11 years (SD 8.68). As in Organisations A and B, almost all of the respondents in Organisation C also worked full time (94 \%) and had permanent employment (98\%). In other words, those who responded to the questionnaire represent their organisations quite well. Background information concerning the survey participants is shown in Table I.

\section{Insert Table I here}

Even if Organisations A, B and C represent different sectors and operate in different fields, they have certain similarities. Firstly, they are all expert organisations in their own field. This can be seen from the background information of the respondents: the educational level in all the organisations is high and most of the respondents in each of the organisations work in expert positions. Secondly, the average age and work experience of the participants is quite high in all three organisations. Importantly, all three organisations also share similar values and strategic goals. Principles like openness, reliability and fairness, effectiveness, innovativeness, growth, profitability and responsibility are highlighted in their value statements and strategic definitions in each organisation.

All three organisations highlight the importance of responsibility and themes like openness and equality. All three organisations promote the idea of doing things correctly and treating fairly both their employees and their stakeholders. Also, one of the core values of all three organisations is effectiveness; this includes for example new and innovative ways of working, continuously developing employees' expertise and skills and paying attention to issues related 
DOES IT PAY TO BE ETHICAL? Original article

Does it pay to be ethical? Examining the relationship between organisations' ethical culture and innovativeness

to occupational well-being such as motivation and working atmosphere, employees' control at work and occupational health services. As responsible, innovative and effective ways of operating are of the essence in these organisations, it seems worth finding out about each one's ethical organisational culture and organisational innovativeness.

\section{Measurements}

The ethical culture of organisations was measured with the CEV (Corporate Ethical Virtues) questionnaire (Kaptein, 2008). The structure of the CEV scale for measuring and evaluating ethical culture has been previously tested and validated by various researchers using Dutch and Finnish data (Kaptein, 2008; Huhtala et al., 2011; Riivari et al. 2012). We used the same scale as Huhtala et al. (2011), which had been first translated from Dutch into Finnish and then back into Dutch, and had been approved by the scale developer. The CEV scale consists of 58 items that comprise eight dimensions of organisational virtues: (1) Clarity (ten items, e.g. "The organization makes it sufficiently clear to me how I should conduct myself appropriately towards others within the organization"); (2) Congruency of supervisor (six items, e.g. "My supervisor sets a good example in terms of ethical behaviour"); (3) Congruency of management (four items, e.g. "The conduct of the Board and (senior) management reflects a shared set of norms and values"); (4) Feasibility (six items, e.g. "In my immediate working environment, I am sometimes asked to do things that conflict with my conscience"); (5) Supportability (six items, e.g. "In my immediate working environment, an atmosphere of mutual trust prevails"); (6) Transparency (seven items, e.g. "If a colleague does something which is not permitted, my manager will find out about it"); (7) Discussability (ten items, e.g. "In my immediate working environment, reports of unethical conduct are handled with caution"); and (8) Sanctionability (nine items, "In my immediate working environment, people are accountable for their actions") (Kaptein, 2008). The items were answered using a 6-point Likert scale from 1 (strongly disagree) to 6 (strongly agree). The six statements for the virtue of feasibility were negatively worded and later reversed for the analysis.

Organisational innovativeness was measured with a 20 -item questionnaire developed and validated by Wang and Ahmed (2004). The questionnaire was also translated twice by a professional translator, first from English into Finnish and then back into English. The questionnaire consists of five groups or dimensions of innovativeness that all include four 
Does it pay to be ethical? Examining the relationship between organisations' ethical culture and innovativeness

statements: product innovativeness (e.g. "Our new products and services are often perceived as very novel by customers"), market innovativeness (e.g. "In new product and services introductions, our organisation is often at the cutting edge of technology), behavioural innovativeness (e.g. "We get a lot of support from managers if we want to try new ways of doing things"), process innovativeness (e.g. "When we cannot solve a problem using conventional methods, we improvise on new methods") and strategic innovativeness (e.g. "Senior executives constantly seek unusual, novel solutions to problems via the use of "idea men"). The items were answered with a 7-point Likert scale, on which 1 denoted "strongly disagree" and 7 denoted "strongly agree". Some items were negatively worded and reversed for the analysis.

Background variables included the respondents' gender (male/female), age (years), education (degree) and position in the organisation (general staff/expert/manager).

\section{Empirical results}

\section{Descriptive results}

Table II presents the means, standard deviations and Cronbach's alphas for the CEV and innovativeness variables. In general, respondents evaluated the ethical culture of their organisation as quite ethical in all the organisations: it received the highest score in Organisation B and the lowest in Organisation C (mean 4.42, range 2-6 in Organisation A; mean 4.63, range 2-6, in Organisation B; and mean 4.30, range 2-6, in Organisation C, on a scale 1-6). In the public sector organisation, A, the highest score for a specific virtue was given to clarity (mean 4.94, range 2-6). In Organisation B the highest score for a specific quality was given to congruency of supervisor (mean 5.20, range 1-6). In Organisation C, the highest score was given to discussability (mean 4.84, range 1-6). Sanctionability received the lowest score of the eight virtues in all the organisations (mean 3.70 in Organisation A, 3.95 in Organisation B and 3.65 in Organisation C, range 1-5 in all organisations). Figure 1 compares the average scores for ethical culture by the three organisations (see Appendix).

\section{Insert Table II here}

Table II Descriptive results for study variables 
Does it pay to be ethical? Examining the relationship between organisations' ethical culture and innovativeness

Organisational innovativeness did not get as good evaluations as the organisation's ethical culture. The evaluations were average, neither particularly high nor particularly low on the seven-point scale (means 3.97 in Organisation A, 4.26 in Organisation B and 4.00 in Organisation C); so organisational innovativeness received the highest score in Organisation B (mean 4.26, range 2-6) and the lowest in Organisation A (mean 3.97, range 2-7). Process innovativeness received the highest score in all the organisations (mean 4.51, range 1-7 in Organisation A; mean 5.18, range 3-7 in Organisation B; mean 4.44, range 1-6 in Organisation C). Overall, all dimensions of organisational innovativeness except market innovativeness received the highest scores in Organisation B. Of the five types, market innovativeness (means 3.51, 3.36 and 3.57) and strategic innovativeness (means 3.63, 3.85 and 3.80) received the lowest scores in all the organisations. Alphas for market innovativeness (0.47 in Organisations A and C; 0.45 in Organisation B) and strategic innovativeness in Organisations A and C (0.49 in A and 0.44 in C) did not exceed the typical 0.6 threshold, which is a signal of low internal consistency. Figure 2 compares the average scores for organisational innovativeness for the three organisations (see Appendix).

\section{Correlation analysis}

Table III presents the correlation matrices of the study variables. Only significant $(p<0.01)$ correlations are reported in the following. As hypothesised, the ethical culture of the organisation correlated positively with the organisation's innovativeness in all organisations $(\mathrm{r}=0.54, \mathrm{p}<0.01$ in Organisation $\mathrm{A} ; \mathrm{r}=0.53, \mathrm{p}<0.01$ in Organisation $\mathrm{B} ; \mathrm{r}=0.70, \mathrm{p}<0.01$ in Organisation C). Also the eight dimensions of ethical culture correlated positively with the five dimensions of organisational innovativeness in all the organisations except in the case of market innovativeness in Organisations A and B. These positive correlations show that the better the evaluations that participants gave to the ethical culture of their organisation, the more likely they were also to evaluate organisational innovativeness on a high level.

\section{Insert Table III here}

Table III Correlation matrices for study variables

All the background variables (gender, age, education and position) had significant correlations with some $\mathrm{CEV}$ dimensions and organisational innovativeness in the public 
Does it pay to be ethical? Examining the relationship between organisations' ethical culture and innovativeness

sector Organisation A. Gender correlated significantly $(\mathrm{p}<0.01)$ with one CEV dimension, congruency of management, showing that women gave lower evaluations to this virtue. Age correlated significantly $(\mathrm{p}<0.01)$ with organisational innovativeness, showing that older respondents evaluated all dimensions of innovativeness except behavioural innovativeness more highly than younger respondents. The correlation between respondents' educational level and their evaluations of organisational innovativeness was negative $(p<0.01)$.

Respondents with a university degree gave lower evaluations to product, process and strategic innovativeness than respondents with non-university degrees. Position correlated positively for some dimensions of ethical culture and organisational innovativeness. Respondents working in higher positions evaluated congruency of management, transparency and process innovativeness more highly than respondents in lower positions.

Of the background variables, age and position correlated significantly $(\mathrm{p}<0.01)$ with organisational innovativeness in the private sector Organisation B. Older respondents gave more positive evaluations to product, process and strategic innovativeness than younger respondents. Respondents working in higher positions gave higher evaluations to clarity and transparency than respondents in lower positions. Correlations between position and innovativeness were also positive, with the exception of market innovativeness, for which the correlations were not significant.

In the private sector Organisation $\mathrm{C}$, age and position correlated significantly $(\mathrm{p}<0.01)$ with ethical culture and organisational innovativeness. Age correlated positively with two dimensions of organisational ethical culture, congruency of supervisor and sanctionability, showing that older respondents gave higher evaluations to these virtues. Position correlated also positively with ethical culture and organisational innovativeness. Respondents working in higher positions gave higher evaluations to congruency of supervisor, congruency of management, transparency and sanctionability than respondents in lower positions. Position correlated also positively with organisational innovativeness. Respondents working in higher positions gave higher evaluations to product, behavioural and process innovativeness than respondents in lower positions.

\section{Multivariate analysis}


Does it pay to be ethical? Examining the relationship between organisations' ethical culture and innovativeness

The relationship between the ethical culture of the organisation and its innovativeness was analysed by means of linear regression analysis. First, we tested the link between the onedimensional models of ethical culture and organisational innovativeness. As the results in Table IV show, there is a positive link between ethical culture and organisational innovativeness in all organisations. In the public sector Organisation A, ethical culture as a one-dimensional model explains 29 per cent of organisational innovativeness (adj. $\mathrm{R}^{2}$ 0.29; F 199.53; $\mathrm{p}<0.001)$. In the private sector Organisation B, ethical culture explains 28 per cent of organisational innovativeness (adj. $\left.\mathrm{R}^{2} 0.28 ; \mathrm{F} 48.19 ; \mathrm{p}<0.001\right)$. In the private sector Organisation $\mathrm{C}$, ethical culture as a one-dimensional model explains 48 per cent of organisational innovativeness (adj. $\mathrm{R}^{2} 0.48$; F 110.24; $\left.\mathrm{p}<0.001\right)$. This supported Hypothesis 1 , and also shows that the link between ethical culture and organisational innovativeness might vary from one organisation to another.

\section{Insert table IV here}

Table IV Regression models for organisational innovativeness and the ethical culture of the organisation

Secondly, we tested the role of different dimensions of ethical culture in different types of organisational innovativeness using linear regression analysis. As the regression models in Table V show, in Organisation A, congruency of management seems to have the most important role in organisational innovativeness, especially in behavioural, process and strategic innovativeness $(\mathrm{p}<0.001)$. All the other dimensions of ethical culture except feasibility and supportability also seem to have a role in organisational innovativeness. Ethical culture seems to be the most important factor in behavioural innovativeness $\left(\mathrm{R}^{2} 0.37\right.$; F35.66; $\mathrm{p}<0.001)$ and process innovativeness $\left(\mathrm{R}^{2} 0.32 ; \mathrm{F} 28.70 ; \mathrm{p}<0.001\right)$. Of the individual dimensions of ethical culture in organisations, congruency of management seems to have the most important role in both behavioural and process innovativeness. Also the virtue of discussability was significantly related to both behavioural and process innovativeness. In addition, the virtues of congruency of supervisor and sanctionability were related to behavioural innovativeness and the virtue of clarity to process innovativeness.

In Organisation B, congruency of supervisor was the only virtue of ethical culture that was positively and almost significantly $(\mathrm{p}<0.05)$ linked to more than one dimension of 
Does it pay to be ethical? Examining the relationship between organisations' ethical culture and innovativeness

organisational innovativeness, process innovativeness and market innovativeness. Also discussability, congruency of management and transparency seem to have a role in organisational innovativeness in Organisation B. As in Organisation A, ethical culture seems to be the most important factor in behavioural innovativeness $\left(\mathrm{R}^{2} 0.35 ; \mathrm{F} 9.20 ; \mathrm{p}<0.001\right)$ and process innovativeness $\left(\mathrm{R}^{2} 0.26 ; \mathrm{F} 6.45 ; \mathrm{p}<0.001\right)$ also in Organisation B. Of the individual dimensions of ethical culture in organisations, congruency of management seems to have the most important role in behavioural innovativeness. In addition, the virtue of congruency of supervisor was positively and the virtue of transparency was negatively related to process innovativeness in Organisation B.

In Organisation $\mathrm{C}$, clarity seems to have the most important role in organisational innovativeness, especially in product, market, process and behavioural innovativeness $(\mathrm{p}<$ $0.05)$. Also congruency of supervisor, congruency of management and transparency seem to have a role in organisational innovativeness in Organisation C. As in Organisations A and B, ethical culture seems to be the most important factor in behavioural innovativeness $\left(\mathrm{R}^{2} 0.38\right.$; F10.08; $\mathrm{p}<0.001)$ and process innovativeness $\left(\mathrm{R}^{2} 0.43 ; \mathrm{F} 12.07 ; \mathrm{p}<0.001\right)$ but it also seems to have a role in product innovativeness $\left(\mathrm{R}^{2} 0.36\right.$; F9.26; $\left.\mathrm{p}<0.001\right)$ in Organisation C. Of the individual dimensions of ethical organisational culture, clarity seems to have the most important role in product, behavioural and process innovativeness. In addition, the virtue of congruency of management was related to product innovativeness, and congruency of supervisor to behavioural innovativeness. Transparency was negatively related to behavioural innovativeness $(\mathrm{p}<0.05)$ in Organisation $\mathrm{C}$.

\section{Insert table V here}

Table V Regression models for organisational innovativeness and dimensions of CEV

To sum up, as the above results show, different dimensions of ethical culture are differently linked to various dimensions of organisational innovativeness. These results provide support for Hypothesis 2 and show that there might be both positive and negative links between different dimensions of ethical culture and the different dimensions of organisational innovativeness.

\section{Discussion}


Does it pay to be ethical? Examining the relationship between organisations' ethical culture and innovativeness

The findings show that participants in the study from all three Finnish organisations evaluated the ethical culture of their organisation relatively positively. Ethical culture received the highest score in Organisation B, a medium-sized industrial services company, and the lowest score in Organisation C, a large industrial services company. This result shows that ethical culture varies from one organisation to another.

Of the individual dimensions of ethical culture, clarity received the highest evaluations in Organisation A and also received high evaluations in Organisations B and C (where it was ranked third of the eight virtues). This result suggests that there are clear and understandable ethical standards and rules in Finnish organisations. This result is in line with the findings of Huhtala et al. (2011) and Riivari et al. (2012), who also found that of the eight ethical dimensions clarity got the best evaluations from Finnish respondents. Our findings and the previous findings of Huhtala et al. (2011) and Riivari et al. (2012) support the idea that Finnish organisations have well thought out rules and official codes of good and ethical conduct, and the principles of ethical behaviour are generally known there. However, as shown in this study, sanctionability received the lowest score in all three organisations, which indicates that even if there are clear official rules and standards for ethical behaviour in Finnish organisations, more emphasis is still needed on the fact that individuals' actions have ethical consequences which must always be taken into consideration. There seem to be challenges in successfully applying the ethical rules and principles in practice. When developing their ethical culture, organisations should concentrate more on ensuring that members know that ethical behaviour will be rewarded and unethical behaviour will be punished.

In Organisations B and C, congruency of supervisor and discussability received the highest scores (ranked first and second of the eight individual dimensions) of the individual virtues. Congruency of supervisor received high evaluations also in the public sector organisation, A (ranked third of the eight virtues). High evaluations for congruency of supervisor show that respondents consider their supervisors to be good examples and role models in terms of following their organisations' ethical standards and values. High evaluations of the discussability dimension show that the private sector organisations in this study offer an open environment in which their members can discuss ethical matters. Also feasibility, which 
Does it pay to be ethical? Examining the relationship between organisations' ethical culture and innovativeness

includes such aspects as time, financial resources, equipment and information, received quite a high score in the public sector organisation, A, but it was not as highly ranked in the private sector organisations. Feasibility also got quite high evaluations in the previous study of Riivari et al. (2012), which was conducted in public sector organisations. This result suggests that there might be some differences between what is seen as important in ethical culture in different organisations and sectors.

Organisational innovativeness received somewhat lower scores than ethical culture. Process innovativeness received the highest score in our study in all three organisations, while market innovativeness and strategic innovativeness received the lowest scores. This result finds support from previous studies. In the study of Riivari et al. (2012), process innovativeness was also found to be one of the most highly evaluated dimensions, while market innovativeness received the lowest score. The results of another study in a Finnish business environment (Ellonen et al., 2008) also support this idea, even if their model of organisational innovativeness was modified and differed somewhat from the model in this study. The results of this paper confirm the finding that evaluations of innovativeness in Finnish organisations are independent of the sector in which the organisation operates. Also in the original study by Wang and Ahmed (2004), process innovativeness was evaluated as one of the highest-level dimensions of organisational innovativeness and market and strategic innovativeness the lowest. Their study was conducted in England, Wales and Scotland, so these evaluations of organisational innovativeness show similarities in different business contexts.

Our first hypothesis was supported by our study results: we found that organisations' ethical culture is positively associated with their organisational innovativeness. This result is also found in the pilot study in the Finnish public sector mentioned above (Riivari et al. 2012). One of the primary contributions of the present study is that it lends empirical support to previous arguments about the connection between organisational culture and innovativeness (e.g. Ahmed, 1998; Martins and Terblanche, 2003). In particular, this study confirms that the ethical culture of an organisation matters when the organisation's desired outcome is innovativeness (cf. Baucus et al., 2008; Ruppel and Harrington, 2000; Riivari et al., 2012). We here provide empirical evidence that there is a positive link between an organisation's ethical culture and its innovativeness, for which there has hitherto been little evidence in the organisational innovativeness literature. 
Does it pay to be ethical? Examining the relationship between organisations' ethical culture and innovativeness

Our second hypothesis was also supported by our results: different dimensions of ethical culture were found to be differently associated with different dimensions of organisational innovativeness in all three organisations. The ethical culture of the organisation had a specific role in process and behavioural innovativeness in all three organisations but also in product innovativeness in the large industrial services organisation. This result suggests that the relationship between ethical culture and organisational innovativeness might vary between organisations, as Organisations A and B both operate in quite strictly regulated fields in the public and private sector.

It was found that different virtues of ethical culture had the highest effect on organisational innovativeness in Organisations A, B and C, but there are also similarities. In general, the ethical culture was found to be the best indicator of organisational innovativeness in the large industrial services company (Organisation C). In the public sector Organisation A, congruence of management was the single dimension with the highest effect on organisational innovativeness overall and specifically on behavioural and process innovativeness. The same virtue was found to be positively associated to market innovativeness in Organisations B and $\mathrm{C}$ and also to product innovativeness in Organisation $\mathrm{C}$. One reason for this may be that when top managers act as role models and show other members of the organisation how to behave ethically, employees trust and respect the management and also identify better with the organisation. In addition, the reputation of the employing organisation is largely dependent on the behaviour of its top management (Paine, 1997). Ethical behaviour at this level indicates that the organisation is a respected and trustworthy place to work, and this contributes to workers' feelings of pride, purposefulness, motivation and inspiration - crucial features for creativity and innovativeness (Martins and Terblanche, 2003; Bassett-Jones, 2005; RoseAnderssen and Allen, 2008). If top management behave unethically, other members of the organisation may see no good reason to contribute to the development and improvement of the organisation. Also Hosmer $(1994,1997)$ suggests that managers' moral behaviour is essential for organisations and their performance in the long run. However, neither he nor his critics Shaw and Corvino (1996) studied the topic empirically. In this study we have tested empirically the relationship between ethical culture and organisational innovativeness and can add to previous discussions that it pays to be ethical if the organisation's objective is organisational innovativeness. 
Does it pay to be ethical? Examining the relationship between organisations' ethical culture and innovativeness

We suggest that organisational innovativeness depends especially on the behaviour of top management, who act as ethical role models, and on consistency between the communication of top management and their actual behaviour. In other words, we believe that it is particularly the ethical leadership behaviour of top management that is significant for an organisation's innovativeness. Organisations can increase ethical leadership behaviour by recruiting ethically conscious top managers and by investing in and deliberately developing these qualities in their work.

Also the virtue of congruency of supervisor was positively associated with process and market innovativeness in Organisation B, and with behavioural innovativeness in Organisations A and C. Along with the result that congruency of management has a special role in organisational innovativeness, this result supports the idea that not only managers but also supervisors are important role models for other organisation members also in relation to the organisation's capacity to create new things and innovate. The ethical virtue of transparency was found to be negatively associated with process innovativeness in Organisation B and with behavioural innovativeness in Organisation C. Transparency refers to awareness of the consequences of one's actions in the organisation, and helps employees to take responsibility for their actions and understand what is expected of them in terms of ethical behaviour (Kaptein, 2008). This result shows that not all the dimensions of ethical culture might be positively associated with organisational innovativeness. Transparency and awareness of one's actions, which are commonly linked to innovativeness, might actually reduce an organisation's member's willingness to be creative and take risks.

\section{Limitations and suggestions for further research}

The limitations of this study must be borne in mind. Our study only captures a view of organisational contexts in Finland, not other societal contexts. However, it gives a fairly broad picture of the topic in Finland and provides information about the role of ethics in organisational innovativeness, a perspective which is rarely seen in business ethics research despite the widespread recognition of the importance of ethics in the organisational context (e.g. Treviño, 1990; Sinclair, 1993; Paine, 1997; Collier, 1998; Treviño et al., 1998; Kaptein, 2008, 2009, 2010, 2011; Solomon, 2004; Sims and Brinkmann, 2009; Crane and Matten, 
Does it pay to be ethical? Examining the relationship between organisations' ethical culture and innovativeness

2007; Pučètaite et al., 2010; Huhtala et al., 2011; Riivari et al., 2012). Since the majority of empirical studies on ethics in an organisational context have been carried out using either European or U.S. data, we think the question of how this topic is understood in other societal contexts is an important one for future research. For example, it might be useful to validate the CEV model used in this study in other contexts.

This research showed that there is a relationship between the ethical organisational culture and the specific organisational outcome of organisational innovativeness. One limitation is that we were unable to study other groups of outcomes, namely employee and financial outcomes (Dyer and Reeves, 1995). In addition, other organisational outcomes, for example productivity and efficiency or such HR outcomes as employees' commitment to the organisation and their work satisfaction, could have been investigated. This research is, however, one of the few empirical studies which focuses on the role of an organisation's ethical policies on its outcomes overall. In future research it would be fruitful to widen the scope of the outcomes.

Since the ethical behaviour of those in top management positions seems to have an important role in organisational innovativeness, we think that the connection between top managers' ethical leadership behaviour, the organisation's ethical culture and its outcomes needs more research in the future. Qualitative methods would provide a more detailed and richer view of the topic. Moreover, the development and maintenance of ethical leadership behaviour merits further research, particularly empirical research.

The data were collected through self-report measures, which raises the question of common method biases that cannot be easily controlled. In future objective outcome measures, for example, could be collected and used in the analysis to increase the reliability of the analysis. The cross-sectional design of the study can also be seen as a limitation. Even if the results of our study suggest a positive relationship between ethical culture and organisations' effectiveness outcomes, longitudinal research is needed to investigate the causal relationship between the phenomena. However, this study has revealed important information about the associations between organisations' ethical culture and different outcomes, and we regard this study as an important contribution to the field of research. As the data for this study were gathered from three organisations, there may also be a limitation related to the number of 
Does it pay to be ethical? Examining the relationship between organisations' ethical culture and innovativeness

samples. Even if all three organisations represent expert organisations, the results of our study cannot be generalised without taking this limitation into account. In future, more diverse study samples should be used to assess the applicability of these findings. However, this study has given us new information about the connections between ethical culture and organisational effectiveness from both public and private sector organisations and from all levels of the organisations, both general staff and managers.

\section{Conclusion}

The findings of our study support previous research results: an organisation's ethical culture has an impact on its organisational outcomes (Treviño et al. 1998; Huhtala et al. 2011, Kaptein, 2011; Riivari et al., 2012). In this study we have shown that ethical culture is associated with the achievement of organisational innovativeness as an organisational outcome. We have also shown that different dimensions of ethical organisation culture are linked to different dimensions of organisational innovativeness. The ethical behaviour of top management and supervisors is important for organisational innovativeness. It can therefore be concluded that when organisations aim to achieve specific outcomes, they need to be aware what dimensions of ethical culture are particularly relevant. Such an awareness would contribute to effective and focused development.

\section{References}

Ahmed, P. K. (1998). Culture and climate of innovation. European Journal of Innovation Management 1(1), 30-43.

Alencar, E. M. L. S. and Bruno-Faria, M. F. (1997). Characteristics of an Organizational Environment Which Stimulate and Inhibit Creativity. Journal of Creative Behavior 31(4), 271-281.

Amabile, T. M. (2008). How to kill creativity. Harward Business Review 76(5), 77-87.

Amabile, T. M., Conti, R., Coon, H., Lazenby, J., and Herron, M. (1996). Assessing the work environment for creativity. Academy of Management Journal 39(5), 1154-1184.

Baregheh, A., Rowley, J. and Sambrook, S. (2009). Towards a multidisciplinary definition of innovation. Management Decision 47(8), 1323-1339. 
Does it pay to be ethical? Examining the relationship between organisations' ethical culture and innovativeness

Bassett-Jones, N. (2005). The Paradox of Diversity Management, Creativity and Innovation. Diversity Management, Creativity and Innovation 14(2), 169-175.

Baucus, M. S., Norton, W. I., Baucus, D. A. and Human, S. H. (2008). Fostering Creativity and Innovation without Encouraging Unethical Behavior. Journal of Business Ethics, 81(1), 97-115.

Belbin, M. R. (1981). Management Teams. John Wiley \& Sons, New York.

Baruch, Y. and Holtom, B. C. (2008), Survey response rate levels and trends in organizational research. Human Relations, 61(8), 1139-1160.

Brown, A. D. (1992). Organizational Culture: The key to Effective Leadership and Organizational Development. Leadership and Organization Development Journal, 13(2), 3-6.

Calantone, R. J., Cavusgil, S. T. and Zhao, Y. (2002). Learning orientation, firm innovation capability, and firm performance. Industrial Marketing Management, 31(8), 515-524.

Carroll, A. B. (1991). The Pyramid of corporate social responsibility: Toward the moral management of organizational stakeholders. Business Horizons 34(4), 39-48.

Chang, L. and Birkett, B. (2004). Managing intellectual capital in a professional service firm: exploring the creativity-productivity paradox. Management Accounting Research 15(1), $7-31$.

Collier, J. (1998). Theorising the ethical organization. Business Ethics Quarterly, 8(4), 621654.

Crane, A. and Matten, D. (2007). Business Ethics. Oxford University Press, Oxford.

Dyer, L. and Reeves, T. (1995). Human resource strategies and firm performance: what do we know and where do we need to go? The International Journal of Human Resource Management 6(3), 656-670.

Ellonen, R., Blomqvist, K. and Puumalainen K. (2008). The role of trust in organisational innovativeness. European Journal of Innovation Management, 11(2), 160-181.

Erdogan, B., Liden B. C. and Kraimer M. L. (2006). Justice and Leader-Member Exchange: The Moderating Role of Organizational Culture. Academy of Management Journal, 49(2), 395-406.

Hosmer, L. T. (1994). Why Be Moral? A Different Rationale for Managers. Business Ethics Quarterly, 4(2), 191-204.

Hosmer, L. T. (1997). Why Be Moral? A Reply to Shaw and Corvino. Business Ethics Quarterly, 4(2), 191-204. 
Does it pay to be ethical? Examining the relationship between organisations' ethical culture and innovativeness

Huhtala, M., Feldt, T., Lämsä, A-M., Mauno, S. and Kinnunen, U. (2011). Does the Ethical Culture of Organisations Promote Managers' Occupational Well-Being? Investigating Indirect Links via Ethical Strain. Journal of Business Ethics 101(2), 231-247.

Huhtala, M., Feldt, T., Hyvönen, K. and Mauno, S. (2012) Ethical Organisational Culture as a Context for Managers' Personal Work Goals. Journal of Business Ethics. Published online 19 May 2012. doi: 10.1007/s10551-012-1346-y

Judge, W.Q., Fryxell, G.E. and Dooley, R.S. (1997). The new task of R\&D management: creating goal-directed communities for innovation. California Management Review 39(3), 72-85.

Kaptein, M. (2008). Developing and testing a measure for the ethical culture of organizations: the corporate ethics virtue model. Journal of Organisational Behaviour 29(7), 923-947.

Kaptein, M. (2009). Ethics programs and ethical culture: A next step in unravelling their multi-faceted relationship. Journal of Business Ethics 89(2), 261-281.

Kaptein, M. (2010). The ethics of organizations: A longitudinal study of the U.S. working population. Journal of Business Ethics 92(4), 601-618.

Kaptein, M. (2011). From Inaction to External Whistleblowing: The Influence of the Ethical Culture of Organizations on Employee Responses to Observed Wrongdoing. Journal of Business Ethics 98(3), 513-530.

Lumpkin, G. T. and Dess, G. G. (1996). Clarifying the entrepreneurial orientation construct and linking it to performance. Academy of Management Review 21(1), 135-172.

Martins, E. C. and Terblanche, F. (2003). Building organizational culture that stimulates creativity and innovation. European Journal of Innovation Management 6(1), 64-74.

Miller, T. and Triana, M. (2009). Demographic Diversity in the Boardroom: Mediators of the Board Diversity-Firm Performance Relationship. Journal of Management Studies 46(5), $755-786$.

Mumford, M. D. (2000). Managing Creative People: Strategies and Tactics for Innovation. Human Resource Management Review 10(3), 313-351.

Nonaka, I. and Takeuchi, H. (1995). The knowledge-creating company: How Japanese companies create the dynamics of innovation. Oxford University Press, New York.

Paine, L. S. (1997). Cases in Leadership, Ethics, and Organizational Integrity. Irwin, Chigago. Pučètaitè, R., Lämsä, A-M. and Novelskaite, A. (2010). Building organizational trust in a low-trust societal context. Baltic Journal of Management, 5(2), 197-217. 
DOES IT PAY TO BE ETHICAL? Original article

Does it pay to be ethical? Examining the relationship between organisations' ethical culture and innovativeness

Quinn, J. B. (2000). Outsourcing innovation: the new engine of growth. Sloan Management Review 41(4), 13-28.

Rebernik, M. and Širec, K. (2007). Fostering innovation by unlearning tacit knowledge. Kybernetes 36(3/4), 406-419.

Rentsch, J. R. (1990). Climate and Culture: Interaction and Qualitative Differences in Organizational Meanings. Journal of Applied Psychology 75(6), 668-681.

Riivari, E., Lämsä, A-M., Kujala, J. and Heiskanen, E. 2012. The ethical culture of organisations and organisational innovativeness. European Journal of Innovation Management 15(3), 310-331.

Roberts, E. B. and Fusfeld, A. R. (1981). Staffing the Innovative Technology-Based Organization. Sloan Management Review 22(3), 19-34.

Roffe, I. (1999). Innovation and creativity in organisations: a review of the implications for training and development. Journal of European Industrial Training 23(4/5), 224-237.

Rose-Anderssen, C. and Allen, P. M. (2008). Diversity and learning for innovation: dialogue for collaboration. Journal of Management Development 27(3), 307-327.

Ruppel, C. P. and Harrington, S. J. (2000). The Relationship of Communication, Ethical Work Climate, and Trust to Commitment and Innovation. Journal of Business Ethics $25,313-328$.

Salavou, H. (2004). The concept of innovativeness: should we need to focus? European Journal of Innovation Management 7(1), 33-44.

Scott, S. G. and Bruce, R. A. (1994). Determinants of innovative behavior: a path model of individual innovation in the workplace. Academy of Management Journal 37(3), 580607.

Shaw, B. and Corvino, J. (1996). Hosmer and the "Why Be Moral?" Question. Business Ethics Quarterly 6(3), 373-383.

Sims, R. R. and Brinkmann, J. (2003). Enron Ethics (Or: Culture Matters More than Codes). Journal of Business Ethics 45(3), 243-256.

Sims, R. R. and Brinkmann, J. (2009). Thoughts and second thoughts about Enron ethics. In Christina Garsten and Tor Hernes (Eds.) Ethical Dilemmas in Management (pp. 105114). Routledge, New York.

Sinclair, A. (1993). Approaches to organisational culture and ethics. Journal of Business Ethics 12(1), 63-73. 
Does it pay to be ethical? Examining the relationship between organisations' ethical culture and innovativeness

Solomon, R. C. (2000). Business with virtue: Maybe next year. Business Ethics Quarterly 10(1), 319-331.

Solomon, R. C. (2004). Aristotle, ethics \& business organisations. Organisation Studies 25(6), 1021-1043.

Treviño, L. K. (1990). A cultural perspective on changing and developing organisational ethics. Research in Organisational Change and Development 4, 195-230.

Treviño, L. K., Butterfield, K. D. and McCabe, D. L. (1998). The Ethical Context in Organisations: Influences on Employee Attitudes and Behaviours. Business Ethics Quarterly 8(3), 447-476.

Treviño, L. K. and Weaver, G. R. (2003). Managing ethics in business organizations: Social scientific perspectives. Stanford University press, Stanford.

Välimäki, S. and Lämsä, A-M. (2010). Critical factors for organizational innovation in the field of diverse human resources. In Schiuma, G., Spender, JC \& Weir, M. (eds.) Conference Proceedings 2010 'International Forum on Knowledge Asset Dynamics', pp. 1-23.

Van de Ven, A. (1986). Central problems in the management of innovation. Management Science 32(5), 590-607.

Victor, B. and Cullen, J.B. (1988). The Organizational Bases of Ethical Work Climates. Administrative Science Quarterly 33(1), 101-125.

Wang, C. L. and Ahmed, P. K. (2004). The development and validation of the organizational innovativeness construct using confirmatory factor analysis. European Journal of Innovation Management 7(4), 303-313.

Westwood, R. and Low, D. R. (2003). The Multicultural Muse: Culture, Creativity and Innovation. International Journal of Cross Cultural Management 3(2), 235-259.

Woodman, R.W., Sawyer, J.E. and Griffin, R.W. (1993). Toward a Theory of Organizational Creativity. Academy of Management Review 18(2), 293-321. 
DOES IT PAY TO BE ETHICAL? Original article

29

Does it pay to be ethical? Examining the relationship between organisations' ethical culture and innovativeness

Table I Participants

\begin{tabular}{|c|c|c|c|c|}
\hline & Organisation A & Organisation $B$ & Organisation $C$ & Total \\
\hline Sample size & 715 & 250 & 430 & 1395 \\
\hline Responses received & 477 & 124 & 118 & 719 \\
\hline Response rate & $67 \%$ & $50 \%$ & $27 \%$ & $51.5 \%$ \\
\hline \multicolumn{5}{|l|}{ Age (years) } \\
\hline Average & 48 & 45 & 44 & 47 \\
\hline Range & $24-66$ & $25-64$ & $24-61$ & $24-66$ \\
\hline $\mathrm{SD}$ & 11.14 & 10.60 & 10.41 & 11.05 \\
\hline \multicolumn{5}{|l|}{ Gender } \\
\hline Male & $40 \%$ & $79 \%$ & $77 \%$ & $52.7 \%$ \\
\hline Female & $60 \%$ & $21 \%$ & $23 \%$ & $47.3 \%$ \\
\hline \multicolumn{5}{|l|}{ Position } \\
\hline Employee & $6 \%$ & & $31 \%$ & $8.8 \%$ \\
\hline Expert/specialist & $83 \%$ & $83 \%$ & $59 \%$ & $79.2 \%$ \\
\hline Manager/supervisor & $11 \%$ & $17 \%$ & $10 \%$ & $12 \%$ \\
\hline \multicolumn{5}{|l|}{ Education } \\
\hline Academic degree $(\%)$ & $78.4 \%$ & $73.4 \%$ & $41.5 \%$ & $71.5 \%$ \\
\hline \multicolumn{5}{|c|}{ Work experience in total (years) } \\
\hline Average & 23 & 20 & 21 & 22 \\
\hline Range & $1-47$ & $1-50$ & $3-42$ & $1-50$ \\
\hline $\mathrm{SD}$ & 11.31 & 11.83 & 10.96 & 11.38 \\
\hline \multicolumn{5}{|c|}{ Work experience in current position (years) } \\
\hline Average & 13 & 8 & 11 & 12 \\
\hline Range & $1-46$ & $1-35$ & $1-37$ & $1-46$ \\
\hline $\mathrm{SD}$ & 9.78 & 5.59 & 8.68 & 9.24 \\
\hline
\end{tabular}


DOES IT PAY TO BE ETHICAL? Original article

Does it pay to be ethical? Examining the relationship between organisations' ethical culture and innovativeness

Table II Descriptive results for CEV and innovativeness variables

\begin{tabular}{|c|c|c|c|c|c|c|c|c|c|c|c|c|c|}
\hline \multirow[b]{2}{*}{ Variables } & \multicolumn{5}{|c|}{ Organisation A: Public sector $(N=477)$} & \multicolumn{4}{|c|}{$\begin{array}{l}\text { Organisation } B \text { : Medium sized industrial } \\
\text { services }(N=124)\end{array}$} & \multicolumn{4}{|c|}{$\begin{array}{l}\text { Organisation } C \text { : Large industrial } \\
\text { services }(N=118)\end{array}$} \\
\hline & Items & Mean & SD & Range & $\begin{array}{l}\text { Cronbach's } \\
\text { alpha }\end{array}$ & Mean & SD & Range & $\begin{array}{l}\text { Cronbach's } \\
\text { alpha }\end{array}$ & Mean & SD & Range & $\begin{array}{l}\text { Cronbach's } \\
\text { alpha }\end{array}$ \\
\hline $\mathrm{CEV}$, total score & 58 & 4.42 & 0.65 & $2-6$ & 0.97 & 4.63 & 0.63 & $2-6$ & 0.97 & 4.30 & 0.70 & $2-6$ & 0.97 \\
\hline 1. CLAR & 10 & 4.94 & 0.65 & $2-6$ & 0.91 & 4.88 & 0.74 & $1-6$ & 0.91 & 4.63 & 0.86 & $2-6$ & 0.95 \\
\hline 2. CONS & 6 & 4.83 & 0.92 & $1-6$ & 0.94 & 5.20 & 0.90 & $1-6$ & 0.94 & 4.64 & 1.03 & $1-6$ & 0.95 \\
\hline 3. CONM & 4 & 4.62 & 0.88 & $1-6$ & 0.92 & 4.81 & 0.96 & $1-6$ & 0.91 & 4.14 & 1.17 & $1-6$ & 0.95 \\
\hline 4. FEAS & 6 & 4.80 & 0.78 & $2-6$ & 0.82 & 4.72 & 0.83 & $3-6$ & 0.78 & 4.38 & 0.87 & $1-6$ & 0.81 \\
\hline 5. SUPP & 6 & 3.95 & 0.95 & $1-6$ & 0.91 & 4.65 & 0.84 & $1-6$ & 0.90 & 4.08 & 0.97 & $1-6$ & 0.91 \\
\hline 6. TRAN & 7 & 3.93 & 0.75 & $2-6$ & 0.84 & 4.10 & 0.66 & $2-6$ & 0.75 & 3.98 & 0.71 & $2-6$ & 0.83 \\
\hline 7. DISC & 10 & 4.75 & 0.97 & $2-7$ & 0.94 & 5.01 & 0.95 & $1-7$ & 0.94 & 4.84 & 0.98 & $1-7$ & 0.95 \\
\hline 8. SANC & 9 & 3.70 & 0.74 & $1-5$ & 0.89 & 3.95 & 0.63 & $1-5$ & 0.83 & 3.65 & 0.72 & $1-5$ & 0.88 \\
\hline OINN, total score & 20 & 3.97 & 0.70 & $2-7$ & 0.90 & 4.26 & 0.73 & $2-6$ & 0.87 & 4.00 & 0.75 & $1-6$ & 0.89 \\
\hline 1. PROD & 4 & 4.31 & 0.92 & $2-7$ & 0.72 & 4.55 & 0.90 & $2-7$ & 0.69 & 4.00 & 0.98 & $1-6$ & 0.77 \\
\hline 2. MARK & 4 & 3.51 & 0.75 & $1-6$ & 0.47 & 3.36 & 0.77 & $1-6$ & 0.45 & 3.57 & 0.69 & $1-5$ & 0.47 \\
\hline 3. BEHA & 4 & 3.89 & 1.15 & $1-7$ & 0.85 & 4.34 & 1.20 & $1-7$ & 0.83 & 4.17 & 1.13 & $1-7$ & 0.84 \\
\hline 4. $\mathrm{PROC}$ & 4 & 4.51 & 0.90 & $1-7$ & 0.71 & 5.18 & 0.96 & $3-7$ & 0.75 & 4.44 & 0.99 & $1-6$ & 0.78 \\
\hline 5. STRA & 4 & 3.63 & 0.96 & $1-7$ & 0.49 & 3.85 & 1.06 & $1-6$ & 0.65 & 3.80 & 0.91 & $1-6$ & 0.44 \\
\hline
\end{tabular}

CEV Corporate Ethical Virtues (total score), CLAR Clarity, CONS Congruency of Supervisor, CONM Congruency of Management, FEAS Feasibility, SUPP Supportability, TRAN Transparency, DISC Discussability, SANC Santionability, OINN Organisational Innovativeness (total score), PROD Product Innovativeness, MARK Market Innovativeness, BEHA Behavioural Innovativeness, PROC Process Innovativeness, STRA Strategic Innovativeness 
DOES IT PAY TO BE ETHICAL? Original article

Does it pay to be ethical? Examining the relationship between organisations' ethical culture and innovativeness

Table III Correlation matrices for study variables

\begin{tabular}{|c|c|c|c|c|c|c|c|c|c|c|c|c|c|c|c|c|c|c|c|}
\hline $\begin{array}{l}\text { Organisation A } \\
(N=477)\end{array}$ & 1. & 2. & 3. & 4. & 5. & 6. & 7. & 8. & 9. & 10. & 11. & 12 & 13. & 14. & 15. & 16. & 17. & 18. & 19. \\
\hline \multicolumn{20}{|l|}{ 1. Gender ${ }^{\mathrm{a}}$} \\
\hline 2. $\mathrm{Age}^{\mathrm{b}}$ & 0.01 & & & & & & & & & & & & & & & & & & \\
\hline 3. Education ${ }^{\mathrm{a}}$ & -0.06 & $-0.41^{* *}$ & & & & & & & & & & & & & & & & & \\
\hline 4. Position ${ }^{\mathrm{a}}$ & $-0.22^{* *}$ & 0.04 & $0.31^{* *}$ & & & & & & & & & & & & & & & & \\
\hline 5. $\mathrm{CEV}^{\mathrm{b}}$ & -0.06 & -0.01 & 0.02 & $0.09^{*}$ & & & & & & & & & & & & & & & \\
\hline 6. $\mathrm{CLAR}^{\mathrm{b}}$ & 0.01 & -0.05 & -0.02 & 0.03 & $0.76^{* *}$ & & & & & & & & & & & & & & \\
\hline 7. $\mathrm{CONS}^{\mathrm{b}}$ & 0.03 & 0.05 & -0.02 & 0.01 & $0.79^{* *}$ & $0.61^{* *}$ & & & & & & & & & & & & & \\
\hline 8. $\mathrm{CONM}^{\mathrm{b}}$ & $-0.13^{* *}$ & -0.02 & 0.03 & $0.13^{* *}$ & $0.87^{* *}$ & $0.59^{* *}$ & $0.65^{* *}$ & & & & & & & & & & & & \\
\hline 9. DISC ${ }^{\mathrm{b}}$ & 0.02 & -0.07 & 0.06 & -0.04 & $0.62^{* *}$ & $0.44^{* *}$ & $0.46^{* *}$ & $0.47^{* *}$ & & & & & & & & & & & \\
\hline 10. FEAS ${ }^{b}$ & -0.05 & 0.02 & -0.08 & -0.01 & $0.75^{* *}$ & $0.52^{* *}$ & $0.63^{* *}$ & $0.67^{* *}$ & $0.42^{* *}$ & & & & & & & & & & \\
\hline 11. SUPP $^{\mathrm{b}}$ & -0.06 & 0.04 & -0.04 & 0.08 & $0.76^{* *}$ & $0.48^{* *}$ & $0.53^{* *}$ & $0.65^{* *}$ & $0.34^{* *}$ & $0.52^{* *}$ & & & & & & & & & \\
\hline 12. TRAN $^{\mathrm{b}}$ & $-0.11^{*}$ & -0.05 & 0.07 & $0.20^{* *}$ & $0.90^{* *}$ & $0.63^{* *}$ & $0.68^{* *}$ & $0.80^{* *}$ & $0.47^{* *}$ & $0.62^{* *}$ & $0.67^{* *}$ & & & & & & & & \\
\hline 13. SANC ${ }^{\mathrm{b}}$ & $0.09^{*}$ & 0.03 & 0.03 & 0.03 & $0.72^{* *}$ & $0.50^{* *}$ & $0.52^{* *}$ & $0.51^{* *}$ & $0.43^{* *}$ & $0.37^{* *}$ & $0.47^{* *}$ & $0.58^{* *}$ & & & & & & & \\
\hline 14. OINN ${ }^{\mathrm{b}}$ & 0.00 & $0.21^{* *}$ & $-0.14^{* *}$ & $0.09^{*}$ & $0.54^{* *}$ & $0.38^{* *}$ & $0.52^{* *}$ & $0.48^{* *}$ & $0.26^{* *}$ & $0.42^{* *}$ & $0.44^{* *}$ & $0.51^{* *}$ & $0.39^{* *}$ & & & & & & \\
\hline 15. PROD $^{\mathrm{b}}$ & -.030 & $0.18^{* *}$ & $-0.12 * *$ & 0.04 & $0.28^{* *}$ & $0.21^{* *}$ & $0.26^{* *}$ & $0.22^{* *}$ & $0.13^{* *}$ & $0.23^{* *}$ & $0.25^{* *}$ & $0.26^{* *}$ & $0.22^{* *}$ & $0.67^{* *}$ & & & & & \\
\hline 16. MARK $^{\mathrm{b}}$ & -.013 & $0.10^{*}$ & 0.01 & 0.01 & $0.20^{* *}$ & 0.08 & $0.17^{* *}$ & $0.19^{* *}$ & 0.04 & $0.17^{* *}$ & $0.21^{* *}$ & $0.18^{* *}$ & $0.17^{* *}$ & $0.60^{* *}$ & $0.41^{* *}$ & & & & \\
\hline 17. $\mathrm{BEHA}^{\mathrm{b}}$ & -.006 & 0.09 & -0.08 & $0.11^{*}$ & $0.59^{* *}$ & $0.47^{* *}$ & $0.53^{* *}$ & $0.54^{* *}$ & $0.31^{* *}$ & $0.43^{* *}$ & $0.44^{* *}$ & $0.57^{* *}$ & $0.39^{* *}$ & $0.81^{* *}$ & $0.29^{* *}$ & $0.30^{* *}$ & & & \\
\hline 18. PROC $^{\mathrm{b}}$ & 0.02 & $0.20^{* *}$ & $-0.14^{* *}$ & $0.15^{* *}$ & $0.53^{* *}$ & $0.37^{* *}$ & $0.53^{* *}$ & $0.48^{* *}$ & $0.25^{* *}$ & $0.39^{* *}$ & $0.40^{* *}$ & $0.47^{* *}$ & $0.41^{* *}$ & $0.84^{* *}$ & $0.46^{* *}$ & $0.37^{* *}$ & $0.67^{* *}$ & & \\
\hline 19. STRA $^{b}$ & 0.02 & $0.20^{* *}$ & $-0.19^{* *}$ & 0.02 & $0.36^{* *}$ & $0.21^{* *}$ & $0.40^{* *}$ & $0.30^{* *}$ & $0.18^{* *}$ & $0.29^{* *}$ & $0.31^{* *}$ & $0.34^{* *}$ & $0.23^{* *}$ & $0.80^{* *}$ & $0.39^{* *}$ & $0.32^{* *}$ & $0.62^{* *}$ & $0.58^{* *}$ & \\
\hline 20. WELL $^{\mathrm{a}}$ & 0.06 & $0.13^{* *}$ & $-0.10^{*}$ & -0.07 & $0.15^{* *}$ & 0.04 & $0.17^{* *}$ & $0.13^{* *}$ & 0.08 & $0.14^{* *}$ & 0.09 & $0.13^{* *}$ & $0.21^{* *}$ & $0.16^{* *}$ & $0.12^{* *}$ & 0.05 & $0.12^{* *}$ & $0.13^{* *}$ & $0.14^{* *}$ \\
\hline
\end{tabular}

CEV Corporate Ethical Virtues (total score), CLAR Clarity, CONS Congruency of Supervisor, CONM Congruency of Management, DISC Discussability, FEAS Feasibility, SUPP Supportability, TRAN Transparency, SANC Santionability, OINN Organisational Innovativeness (total score), PROD Product Innovativeness,

MARK Market Innovativeness, BEHA Behavioural Innovativeness, PROC Process Innovativeness, STRA Strategic Innovativeness, WELL Occupational well-being

${ }^{\text {a }}$ Spearman correlation for dichotomous/categorical variables

${ }^{\mathrm{b}}$ Pearson correlation for continuous variables

${ }^{*} \mathrm{p}<0.05,{ }^{* *} \mathrm{p}<0.01$ 
DOES IT PAY TO BE ETHICAL? Original article

Does it pay to be ethical? Examining the relationship between organisations' ethical culture and innovativeness

\begin{tabular}{|c|c|c|c|c|c|c|c|c|c|c|c|c|c|c|c|c|c|c|c|}
\hline Organisation $B(N=124)$ & 1. & 2. & 3. & 4. & 5. & 6. & 7. & 8. & 9. & 10. & 11. & 12 & 13. & 14. & 15. & 16. & 17. & 18. & 19. \\
\hline \multicolumn{20}{|l|}{ 1. Gender ${ }^{\mathrm{a}}$} \\
\hline 2. $\mathrm{Age}^{\mathrm{b}}$ & -0.06 & & & & & & & & & & & & & & & & & & \\
\hline 3. Education ${ }^{\mathrm{a}}$ & -0.01 & $-0.38^{* *}$ & & & & & & & & & & & & & & & & & \\
\hline 4. Position ${ }^{a}$ & -0.13 & $0.21^{*}$ & $0.19^{*}$ & & & & & & & & & & & & & & & & \\
\hline 5. $\mathrm{CEV}^{\mathrm{b}}$ & -0.06 & 0.09 & -0.06 & $0.27^{* *}$ & & & & & & & & & & & & & & & \\
\hline 6. $\mathrm{CLAR}^{\mathrm{b}}$ & -0.03 & 0.10 & 0.00 & $0.29^{* *}$ & $0.80^{* *}$ & & & & & & & & & & & & & & \\
\hline 7. $\mathrm{CONS}^{\mathrm{b}}$ & -0.04 & 0.07 & -0.07 & 0.09 & $0.80^{* *}$ & $0.66^{* *}$ & & & & & & & & & & & & & \\
\hline 8. $\mathrm{CONM}^{\mathrm{b}}$ & -0.10 & -0.04 & -0.01 & $0.18^{*}$ & $0.85^{* *}$ & $0.59^{* *}$ & $0.62^{* *}$ & & & & & & & & & & & & \\
\hline 9. DISC $^{\mathrm{b}}$ & 0.15 & 0.05 & -0.03 & 0.08 & $0.58^{* *}$ & $0.39^{* *}$ & $0.46^{* *}$ & $0.46^{* *}$ & & & & & & & & & & & \\
\hline 10. FEAS $^{\text {b }}$ & -0.03 & $0.18^{*}$ & -0.09 & 0.15 & $0.87^{* *}$ & $0.72^{* *}$ & $0.72^{* *}$ & $0.72^{* *}$ & $0.42^{* *}$ & & & & & & & & & & \\
\hline 11. SUPP ${ }^{b}$ & -0.03 & -0.03 & -0.02 & $0.19^{*}$ & $0.69^{* *}$ & $0.41^{* *}$ & $0.46^{* *}$ & $0.59^{* *}$ & $0.23^{*}$ & $0.57^{* *}$ & & & & & & & & & \\
\hline 12. TRAN $^{\mathrm{b}}$ & -0.11 & 0.14 & 0.05 & $0.34^{* *}$ & $0.88^{* *}$ & $0.65^{* *}$ & $0.69^{* *}$ & $0.75^{* *}$ & $0.42^{* *}$ & $0.73^{* *}$ & $0.61^{* *}$ & & & & & & & & \\
\hline 13. SANC & -0.01 & 0.13 & -0.11 & $0.21^{*}$ & $0.76^{* *}$ & $0.58^{* *}$ & $0.50^{* *}$ & $0.53^{* *}$ & $0.28^{* *}$ & $0.63^{* *}$ & $0.49^{* *}$ & $0.62^{* *}$ & & & & & & & \\
\hline 14. OINN & $-0.20^{*}$ & $0.23^{* *}$ & -0.01 & $0.39^{* *}$ & $0.53^{* *}$ & $0.38^{* *}$ & $0.46^{* *}$ & $0.52^{* *}$ & $0.27^{* *}$ & $0.46^{* *}$ & $0.36^{* *}$ & $0.52^{\text {** }}$ & $0.36^{* *}$ & & & & & & \\
\hline 15. $\mathrm{PROD}^{\mathrm{b}}$ & -0.17 & $0.27^{* *}$ & -0.09 & $0.31^{* *}$ & $0.33^{* *}$ & $0.18^{*}$ & $0.25^{* *}$ & $0.35^{* *}$ & 0.10 & $0.30^{* *}$ & $0.30^{* *}$ & $0.36^{* *}$ & $0.24^{* *}$ & $0.72^{* *}$ & & & & & \\
\hline 16. MARK ${ }^{\mathrm{b}}$ & -0.02 & 0.13 & -0.06 & 0.10 & 0.14 & -0.00 & $0.21^{*}$ & 0.07 & 0.10 & 0.15 & $0.19^{*}$ & 0.13 & 0.06 & $0.55^{* *}$ & $0.35^{* *}$ & & & & \\
\hline 17. BEHA $^{\mathrm{b}}$ & -0.18 & 0.07 & 0.05 & $0.36^{* *}$ & $0.58^{* *}$ & $0.42^{* *}$ & $0.42^{* *}$ & $0.60^{* *}$ & $0.34^{* *}$ & $0.48^{* *}$ & $0.38^{* *}$ & $0.55^{* *}$ & $0.35^{* *}$ & $0.82^{* *}$ & $0.41^{* *}$ & $0.25^{* *}$ & & & \\
\hline 18. PROC $^{\mathrm{b}}$ & -0.13 & $0.18^{*}$ & 0.04 & $0.36^{* *}$ & $0.48^{* *}$ & $0.48^{* *}$ & $0.40^{* *}$ & $0.42^{* *}$ & $0.22^{*}$ & $0.40^{* *}$ & $0.18^{*}$ & $0.45^{* *}$ & $0.39^{\text {** }}$ & $0.78^{* *}$ & $0.55^{* *}$ & $0.24^{* *}$ & $0.55^{* *}$ & & \\
\hline 19. STRA $^{\text {b }}$ & -0.13 & $0.24^{* *}$ & -0.06 & $0.25^{* *}$ & $0.37^{* *}$ & $0.25^{* *}$ & $0.36^{* *}$ & $0.38^{* *}$ & $0.20^{*}$ & $0.32^{* *}$ & $0.27^{* *}$ & $0.37^{* *}$ & $0.23^{* *}$ & $0.83^{* *}$ & $0.43^{* *}$ & $0.38^{* *}$ & $0.67^{* *}$ & $0.54^{* *}$ & \\
\hline 20. WELL $^{\mathrm{a}}$ & -0.16 & 0.16 & -0.15 & 0.10 & $0.18^{*}$ & $0.26^{* *}$ & $0.20^{*}$ & 0.03 & $-0.22^{*}$ & $0.24^{* *}$ & $0.28^{* *}$ & $0.20^{*}$ & $0.22^{*}$ & 0.09 & 0.14 & -0.02 & -0.03 & 0.16 & -0.02 \\
\hline
\end{tabular}

CEV Corporate Ethical Virtues (total score), CLAR Clarity, CONS Congruency of Supervisor, CONM Congruency of Management, DISC Discussability, FEAS

Feasibility, SUPP Supportability, TRAN Transparency, SANC Santionability, OINN Organisational Innovativeness (total score), PROD Product Innovativeness,

MARK Market Innovativeness, BEHA Behavioural Innovativeness, PROC Process Innovativeness, STRA Strategic Innovativeness, WELL Occupational well-being

${ }^{\text {a }}$ Spearman correlation for dichotomous/categorical variables

Pearson correlation for continuous variables

$\mathrm{p}<0.05,{ }^{* *} \mathrm{p}<0.01$ 
DOES IT PAY TO BE ETHICAL? Original article

Does it pay to be ethical? Examining the relationship between organisations' ethical culture and innovativeness

\begin{tabular}{|c|c|c|c|c|c|c|c|c|c|c|c|c|c|c|c|c|c|c|c|}
\hline Organisation $C(N=118)$ & 1. & 2. & 3. & 4. & 5. & 6. & 7. & 8. & 9. & 10. & 11. & 12 & 13. & 14. & 15. & 16. & 17. & 18. & 19. \\
\hline \multicolumn{20}{|l|}{ 1. Gender ${ }^{\mathrm{a}}$} \\
\hline 2. $\mathrm{Age}^{\mathrm{b}}$ & -0.07 & & & & & & & & & & & & & & & & & & \\
\hline 3. Education ${ }^{a}$ & 0.03 & $-0.40^{* *}$ & & & & & & & & & & & & & & & & & \\
\hline 4. Position ${ }^{a}$ & $-0.26^{* *}$ & 0.15 & $0.31^{* *}$ & & & & & & & & & & & & & & & & \\
\hline 5. $\mathrm{CEV}^{\mathrm{b}}$ & -0.08 & 0.18 & -0.04 & $0.21^{*}$ & & & & & & & & & & & & & & & \\
\hline 6. $\mathrm{CLAR}^{\mathrm{b}}$ & -0.11 & 0.16 & -0.09 & 0.06 & $0.80^{* *}$ & & & & & & & & & & & & & & \\
\hline 7. $\mathrm{CONS}^{\mathrm{b}}$ & -0.11 & $0.26^{* *}$ & 0.07 & $0.37^{* *}$ & $0.71^{* *}$ & $0.55^{* *}$ & & & & & & & & & & & & & \\
\hline 8. $\mathrm{CONM}^{\mathrm{b}}$ & $-0.21^{*}$ & 0.06 & 0.06 & $0.28^{* *}$ & $0.89^{* *}$ & $0.66^{* *}$ & $0.63^{* *}$ & & & & & & & & & & & & \\
\hline 9. DISC $^{\mathrm{b}}$ & 0.06 & 0.02 & -0.14 & -0.09 & $0.68^{* *}$ & $0.56^{* *}$ & $0.40^{* *}$ & $0.54^{* *}$ & & & & & & & & & & & \\
\hline 10. FEAS $^{\mathrm{b}}$ & -0.11 & 0.08 & 0.03 & 0.07 & $0.81^{* *}$ & $0.55^{* *}$ & $0.60^{* *}$ & $0.71^{* *}$ & $0.59^{* *}$ & & & & & & & & & & \\
\hline 11. SUPP ${ }^{\mathrm{b}}$ & -0.08 & 0.05 & 0.02 & 0.10 & $0.82^{* *}$ & $0.59^{* *}$ & $0.50^{* *}$ & $0.68^{* *}$ & $0.50^{* *}$ & $0.69^{* *}$ & & & & & & & & & \\
\hline 12. TRAN ${ }^{b}$ & -0.14 & 0.10 & -0.00 & $0.29^{* *}$ & $0.87^{* *}$ & $0.68^{* *}$ & $0.66^{* *}$ & $0.79^{* *}$ & $0.44^{* *}$ & $0.64^{* *}$ & $0.68^{* *}$ & & & & & & & & \\
\hline 13. SANC & 0.00 & $0.27^{* *}$ & -0.09 & $0.22^{*}$ & $0.69^{* *}$ & $0.47^{* *}$ & $0.30^{* *}$ & $0.49^{* *}$ & $0.38^{* *}$ & $0.39^{* *}$ & $0.55^{* *}$ & $0.53^{* *}$ & & & & & & & \\
\hline 14. OINN ${ }^{b}$ & -0.08 & 0.14 & -0.08 & $0.35^{\text {** }}$ & $0.70^{* *}$ & $0.57^{* *}$ & $0.54^{* *}$ & $0.58^{* *}$ & $0.42^{* *}$ & $0.55^{* *}$ & $0.50^{* *}$ & $0.62^{* *}$ & $0.57^{* *}$ & & & & & & \\
\hline 15. PROD $^{\mathrm{b}}$ & -0.04 & $0.19^{*}$ & -0.08 & $0.28^{* *}$ & $0.57^{* *}$ & $0.43^{* *}$ & $0.51^{* *}$ & $0.43^{* *}$ & $0.33^{* *}$ & $0.49^{* *}$ & $0.40^{\text {** }}$ & $0.53^{* *}$ & $0.47^{* *}$ & $0.83^{* *}$ & & & & & \\
\hline 16. MARK $^{\mathrm{b}}$ & 0.05 & $0.21^{*}$ & $-0.21^{*}$ & 0.10 & $0.42^{* *}$ & $0.34^{* *}$ & $0.40^{* *}$ & $0.25^{* *}$ & $0.24^{*}$ & $0.32^{* *}$ & $0.34^{* *}$ & $0.36^{* *}$ & $0.42^{* *}$ & $0.67^{* *}$ & $0.63^{* *}$ & & & & \\
\hline 17. BEHA $^{\mathrm{b}}$ & -0.05 & 0.01 & 0.01 & $0.25^{\text {** }}$ & $0.61^{* *}$ & $0.55^{* *}$ & $0.45^{* *}$ & $0.54^{* *}$ & $0.43^{* *}$ & $0.45^{* *}$ & $0.38^{* *}$ & $0.54^{* *}$ & $0.45^{* *}$ & $0.81^{\text {** }}$ & $0.53^{* *}$ & $0.31^{* *}$ & & & \\
\hline 18. PROC & -0.07 & 0.05 & -0.01 & $0.45^{* *}$ & $0.64^{* *}$ & $0.52^{* *}$ & $0.49^{* *}$ & $0.59^{* *}$ & $0.32^{* *}$ & $0.49^{* *}$ & $0.46^{* *}$ & $0.60^{* *}$ & $0.51^{\text {** }}$ & $0.88^{* *}$ & $0.67^{* *}$ & $0.54^{* *}$ & $0.65^{* *}$ & & \\
\hline 19. STRA $^{b}$ & -0.14 & 0.11 & -0.15 & 0.15 & $0.51^{* *}$ & $0.40^{* *}$ & $0.32^{* *}$ & $0.45^{* *}$ & $0.35^{* *}$ & $0.40^{* *}$ & $0.43^{* *}$ & $0.41^{* *}$ & $0.41^{* *}$ & $0.79^{* *}$ & $0.52^{* *}$ & $0.38^{* *}$ & $0.62^{* *}$ & $0.62^{* *}$ & \\
\hline 20. WELL $^{\mathrm{a}}$ & $-0.39^{* *}$ & -0.13 & -0.15 & -0.17 & 0.04 & 0.09 & -0.07 & 0.01 & 0.03 & 0.01 & 0.16 & 0.08 & 0.07 & -0.05 & -0.02 & -0.10 & -0.10 & -0.08 & 0.14 \\
\hline $\begin{array}{l}\text { CEV Corporate Ethical } \\
\text { Feasibility, SUPP Suppor } \\
\text { MARK Market Innovativ } \\
\text { a Spearman correlation fo } \\
{ }^{\mathrm{b}} \text { Pearson correlation for } \\
{ }^{*} \mathrm{p}<0.05,{ }^{* *} \mathrm{p}<0.01\end{array}$ & $\begin{array}{l}\text { irtues (to } \\
\text { tability, } \\
\text { eness, B } \\
\text { dichotc } \\
\text { ontinuo }\end{array}$ & $\begin{array}{l}\text { TRAN } \\
\text { EHA Be } \\
\text { mous/c } \\
\text { us varial }\end{array}$ & $\begin{array}{l}\text { laviou } \\
\text { tegoric } \\
\text { les }\end{array}$ & varia & les & S Con & uency & ss In & visor, & $\overline{\mathrm{ONM}}$ & Oongru & ccy of & Ianage & ness, & SC Di & ussabi & ity, FE & $\begin{array}{l}\mathrm{AS} \\
\text { ss, } \\
\text {-being }\end{array}$ & \\
\hline
\end{tabular}


DOES IT PAY TO BE ETHICAL? Original article

34

Does it pay to be ethical? Examining the relationship between organisations' ethical culture and innovativeness

Table IV Regression models for organisational innovativeness and ethical culture of organisation

\begin{tabular}{|c|c|c|c|c|c|c|c|c|c|}
\hline \multirow[b]{2}{*}{ Model fit } & \multicolumn{9}{|c|}{ Dependent variable } \\
\hline & Adj. $R^{2}$ & $F(d f)$ & & Adj. $R^{2}$ & $F(d f)$ & & Adj. $R^{2}$ & $F(d f)$ & \\
\hline Independent variable & Beta & $\mathrm{T}$ & Sig. & Beta & $\mathrm{T}$ & Sig. & Beta & $\mathrm{T}$ & Sig. \\
\hline Ethical culture of organisation & 0.59 & 14.13 & $0.000^{* * *}$ & 0.62 & 6.94 & $0.000^{* * *}$ & 0.75 & 10.50 & $0.000^{* * *}$ \\
\hline
\end{tabular}


DOES IT PAY TO BE ETHICAL? Original article

35

Does it pay to be ethical? Examining the relationship between organisations' ethical culture and innovativeness

Table V Regression models for organisational innovativeness and dimensions of CEV

\begin{tabular}{|c|c|c|c|c|c|c|c|c|c|c|c|c|c|c|c|}
\hline \multirow{3}{*}{$\begin{array}{l}\text { Dimensions of innovativeness } \\
\text { Model fit }\end{array}$} & \multicolumn{12}{|c|}{ Dependent variable } & & & \\
\hline & \multicolumn{3}{|c|}{ Product innovativeness } & \multicolumn{3}{|c|}{ Market innovativeness } & \multicolumn{3}{|c|}{ Behavioural innovativeness } & \multicolumn{3}{|c|}{ Process innovativeness } & \multicolumn{3}{|c|}{ Strategic innovativeness } \\
\hline & Adj. $R^{2}$ & \multicolumn{2}{|c|}{$F(d f)$} & Adj. $\mathrm{R}^{2}$ & & Adj. $\mathrm{R}^{2}$ & \multicolumn{2}{|c|}{$\mathrm{F}(\mathrm{df})$} & Adj. $R^{2}$ & & Adj. $\mathrm{R}^{2}$ & \multicolumn{2}{|c|}{$F(d f)$} \\
\hline \multirow[t]{2}{*}{ Organisation A $(\mathrm{N}=477)$} & 0.08 & \multicolumn{2}{|c|}{$2.87^{* *}$} & 0.05 & 4.32 & & 0.37 & \multicolumn{2}{|c|}{$35.66^{* * *}$} & 0.32 & \multicolumn{2}{|c|}{$28.70^{* * *}$} & 0.17 & \multicolumn{2}{|c|}{$13.14^{* * *}$} \\
\hline & \multicolumn{3}{|c|}{$(8 ; 468)$} & \multicolumn{3}{|c|}{$(8 ; 468)$} & \multicolumn{3}{|c|}{$(8 ; 468)$} & \multicolumn{3}{|c|}{$(8 ; 468)$} & & \multicolumn{2}{|c|}{$(8 ; 468)$} \\
\hline Independent variables & Beta & $T$ & Sig. & Beta & $T$ & Sig. & Beta & $T$ & Sig. & Beta & $T$ & Sig. & Beta & $T$ & Sig. \\
\hline Clarity & 0.10 & 1.24 & 0.22 & 0.12 & 1.79 & 0.07 & 0.03 & 0.391 & 0.70 & 0.20 & 2.94 & $0.00^{* *}$ & 0.01 & 0.10 & 0.92 \\
\hline Congruency of supervisor & 0.01 & 0.16 & 0.87 & -0.09 & -1.77 & 0.08 & 0.14 & 2.11 & $0.04^{*}$ & -0.03 & -0.52 & 0.60 & -0.12 & -1.98 & 0.05 \\
\hline Congruency of management & 0.12 & 1.63 & 0.11 & 0.05 & 0.92 & 0.36 & 0.26 & 3.57 & $0.000^{* * *}$ & 0.34 & 5.59 & $0.000^{* * *}$ & 0.36 & 5.12 & $0.000^{* * *}$ \\
\hline Feasibility & -0.04 & -0.58 & 0.57 & -0.09 & -1.74 & 0.08 & -0.04 & -0.66 & 0.51 & -0.08 & -1.52 & 0.13 & -0.03 & -0.48 & 0.63 \\
\hline Supportability & 0.06 & 1.01 & 0.27 & 0.05 & 1.00 & 0.32 & -0.01 & -0.21 & 0.84 & 0.02 & 0.31 & 0.76 & 0.04 & 0.68 & 0.50 \\
\hline Transparency & 0.13 & 1.69 & 0.09 & 0.13 & 2.04 & $0.04^{*}$ & 0.06 & 0.773 & 0.44 & 0.07 & 1.13 & 0.26 & 0.16 & 2.10 & $0.04^{*}$ \\
\hline Discussability & -0.06 & -0.81 & 0.42 & 0.07 & 1.14 & 0.25 & 0.19 & 2.41 & $0.02^{*}$ & 0.16 & 2.57 & $0.01^{*}$ & -0.03 & -0.42 & 0.68 \\
\hline Sanctionability & 0.11 & 1.01 & 0.28 & -0.02 & -0.18 & 0.86 & 0.34 & 3.07 & $0.00^{* *}$ & 0.02 & 0.25 & 0.80 & 0.14 & 1.38 & 0.17 \\
\hline Model fit & $\operatorname{Adj} . R^{2}$ & $F(d f)$ & & Adj. $R^{2}$ & $F(\mathrm{df})$ & & Adj. $R^{2}$ & $F(\mathrm{df})$ & & Adj. $R^{2}$ & $F(d f)$ & & Adj. $R^{2}$ & $\mathrm{~F}(\mathrm{df}$ & \\
\hline \multirow[t]{2}{*}{ Organisation $B(N=124)$} & 0.11 & $11.76^{* *}$ & & 0.06 & & & 0.35 & & & 0.26 & $6.45^{* * *}$ & & 0.12 & $3.15^{*}$ & \\
\hline & \multicolumn{3}{|c|}{$(8 ; 115)$} & \multicolumn{3}{|c|}{$(8 ; 115)$} & & $(8 ; 11$ & & & $(8 ; 115$ & & & $(8 ; 1)$ & \\
\hline Independent variables & Beta & $T$ & Sig. & Beta & $T$ & Sig. & Beta & $T$ & Sig. & Beta & $T$ & Sig. & Beta & $T$ & Sig. \\
\hline Clarity & 0.02 & 0.13 & 0.89 & -0.05 & -0.37 & 0.71 & -0.05 & -0.28 & 0.78 & 0.18 & 1.28 & 0.20 & -0.02 & -0.13 & 0.90 \\
\hline Congruency of supervisor & -0.15 & -1.11 & 0.27 & -0.26 & -2.23 & $0.03^{*}$ & 0.05 & 0.30 & 0.77 & 0.30 & 2.32 & $0.02^{*}$ & -0.10 & -0.63 & 0.53 \\
\hline Congruency of management & 0.02 & 0.18 & 0.86 & 0.25 & 2.16 & $0.03^{*}$ & -0.05 & -0.31 & 0.75 & 0.06 & 0.49 & 0.63 & 0.23 & 1.54 & 0.12 \\
\hline Feasibility & -0.10 & -0.88 & 0.38 & 0.05 & 0.51 & 0.61 & 0.09 & 0.72 & 0.48 & -0.06 & -0.57 & 0.57 & -0.02 & -0.12 & 0.91 \\
\hline Supportability & 0.07 & 0.38 & 0.70 & 0.16 & 1.02 & 0.31 & 0.01 & 0.03 & 0.98 & -0.09 & -0.54 & 0.59 & -0.02 & -0.11 & 0.91 \\
\hline Transparency & 0.09 & 0.55 & 0.58 & 0.21 & 1.54 & 0.13 & -0.04 & -0.23 & 0.82 & -0.33 & -2.14 & $0.04^{*}$ & 0.03 & 0.14 & 0.89 \\
\hline Discussability & 0.18 & 1.34 & 0.18 & -0.15 & -1.30 & 0.20 & 0.51 & 3.38 & $0.00^{* *}$ & 0.21 & 1.60 & 0.11 & 0.23 & 1.49 & 0.14 \\
\hline Sanctionability & 0.34 & 1.52 & 0.13 & 0.04 & 0.18 & 0.86 & 0.47 & 1.81 & 0.07 & 0.31 & 1.40 & 0.17 & 0.23 & 0.86 & 0.39 \\
\hline Model fit & Adj. $R^{2}$ & $F(d f)$ & & Adj. $\mathrm{R}^{2}$ & $\mathrm{~F}(\mathrm{df})$ & & Adj. $R^{2}$ & $F(d f)$ & & Adj. $R^{2}$ & $F(d f)$ & & Adj. $R^{2}$ & $\mathrm{~F}(\mathrm{df}$ & \\
\hline Organisation $\mathrm{C}(\mathrm{N}=118)$ & 0.36 & $9.26^{* *}$ & & 0.22 & 5.2 & & 0.38 & 10. & & 0.43 & $12.07^{*}$ & & 0.22 & & \\
\hline & & $(8 ; 109)$ & & & $(8 ; 10$ & & & $(8 ; 10$ & & & $(8 ; 109$ & & & $(8 ; 10$ & \\
\hline Independent variables & Beta & $T$ & Sig. & Beta & $T$ & Sig. & Beta & $T$ & Sig. & Beta & $T$ & Sig. & Beta & $T$ & Sig. \\
\hline Clarity & 0.35 & 3.25 & $0.00^{* *}$ & 0.26 & 3.17 & $0.00^{* *}$ & 0.30 & 2.49 & $0.01^{*}$ & 0.33 & 3.24 & $0.00^{* *}$ & 0.21 & 1.90 & 0.06 \\
\hline Congruency of supervisor & 0.01 & 0.13 & 0.90 & 0.06 & 0.73 & 0.47 & 0.26 & 2.13 & $0.04^{*}$ & 0.13 & 1.27 & 0.21 & 0.08 & 0.68 & 0.50 \\
\hline
\end{tabular}


DOES IT PAY TO BE ETHICAL? Original article

36

Does it pay to be ethical? Examining the relationship between organisations' ethical culture and innovativeness

\begin{tabular}{|c|c|c|c|c|c|c|c|c|c|c|c|c|c|c|c|}
\hline Congruency of management & 0.21 & 2.40 & $0.01^{*}$ & 0.19 & 2.77 & $0.01^{*}$ & 0.09 & 0.91 & 0.37 & 0.09 & 1.08 & 0.28 & 0.00 & 0.04 & 0.97 \\
\hline Feasibility & -0.01 & -0.09 & 0.93 & -0.01 & -0.10 & 0.92 & 0.12 & 0.90 & 0.37 & -0.14 & -1.29 & 0.20 & 0.05 & 0.39 & 0.70 \\
\hline Supportability & 0.25 & 2.00 & 0.05 & 0.05 & 0.54 & 0.59 & 0.09 & 0.61 & 0.55 & 0.15 & 1.28 & 0.20 & 0.09 & 0.67 & 0.51 \\
\hline Transparency & -0.20 & -1.22 & 0.23 & 0.05 & 0.36 & 0.72 & -0.38 & -2.04 & $0.04^{*}$ & -0.19 & -1.21 & 0.22 & 0.12 & 0.67 & 0.50 \\
\hline Discussability & -0.06 & -0.50 & 0.62 & -0.16 & -1.67 & 0.10 & 0.20 & 1.43 & 0.16 & 0.22 & 1.87 & 0.07 & 0.13 & 1.01 & 0.31 \\
\hline Sanctionability & 0.25 & 1.3 & 0.19 & 0.01 & 0.07 & 0.94 & 0.21 & 0.98 & 0.33 & 0.22 & 1.27 & 0.21 & -0.00 & -0.01 & 0.99 \\
\hline
\end{tabular}


DOES IT PAY TO BE ETHICAL? Original article

Does it pay to be ethical? Examining the relationship between organisations' ethical culture and innovativeness

Appendix
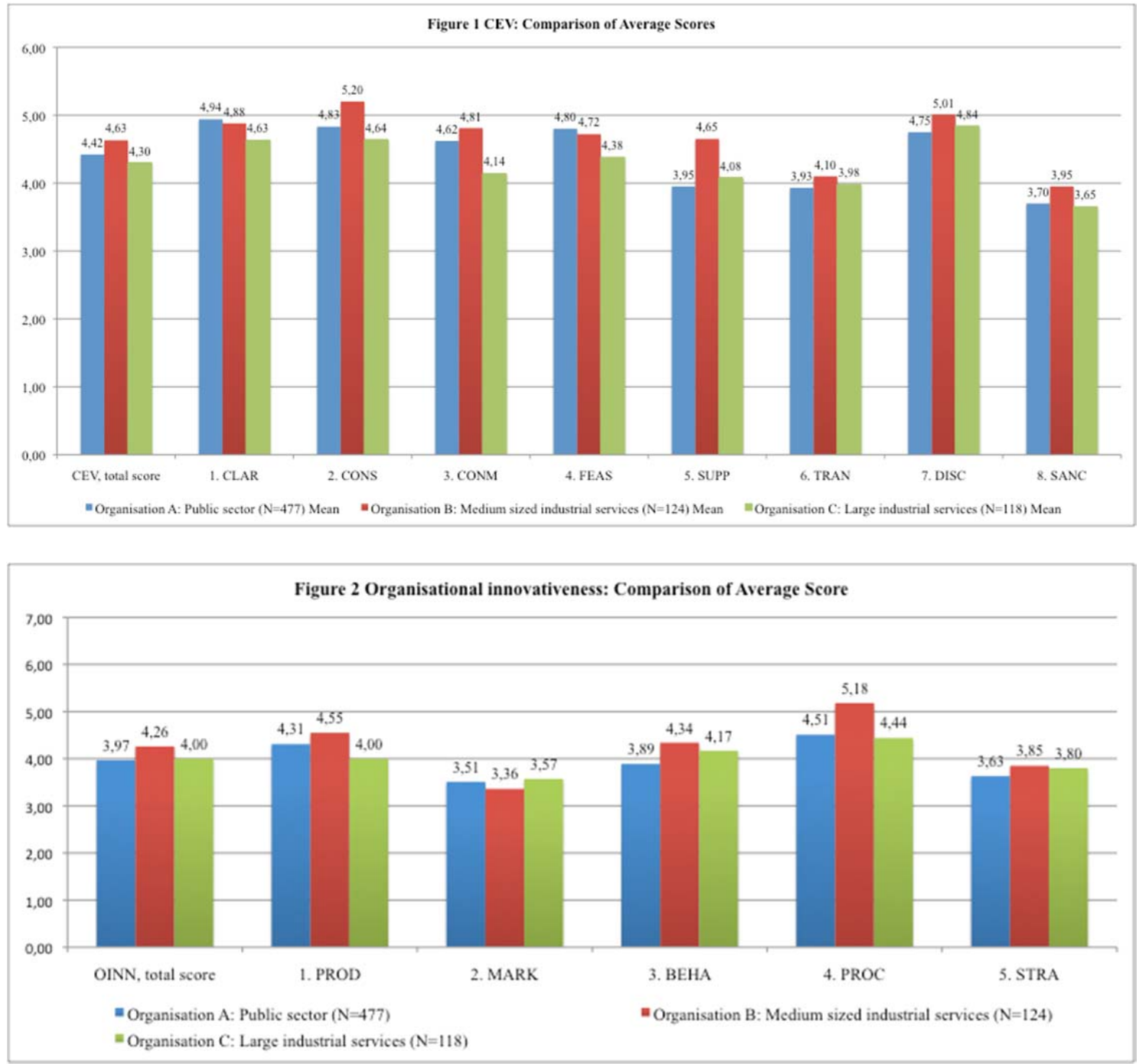